\title{
TURCO-BRITISH RAPPROCHEMENT ON THE EVE OF THE SECOND WORLD WAR
}

\author{
YÜCEL GÜÇLÜ
}

The First World War failed to resolve the basic conflicts among the European powers. The injustices inherent in the Versailles peace settlement only worsened the complicated national questions which bedevilled the whole of Europe. The military, political and economic developments which followed 1918 drove the European world towards a new grouping of powers.

At the beginning of the 1930s the countries of the Balkan Peninsula once more became the stage in an acute struggle among the largest nations in the world. The interests of Britain, France, Germany and Italy clashed, as the Balkan countries occupied a crucial position on the East-West route. The conflicts among the greater European states, sharpened on the eve of the Second World War, aggravated the political situation in the Balkans and impeded the realisation of the regional diplomatic plans of both Western countrics and of Nazi Germany and Fascist Italy. Hence a closer scrutiny of the distribution of power in southeastern Europe and the Near East during the late 1930s, as well as the policy of the great powers vis-à-vis this area may help to better grasp the complex international configuration prevailing in Europe on the brink of war.

Continuing its traditional policy of balance of power in Europe long after the First World War, Britain contributed considerably to the rehabilitation of Germany as a military and political power on the European continent intended to counterbalance the excessive strengthening of France. All German efforts to weaken the French influence were welcomed by the British government. 
In the early and mid thirties Britain did not want to be officially bound or in any way committed to the countries of central and southeastern Europe. The desire not to provoke the displeasure of Germany and Italy and not to hinder a possible agreement with them left its mark on the overall political line pursued by the British government during this period. However, the increase in the economic and military potential of Germany and its ever stronger claims for world domination endangered the economic, strategic and political position of Britain in the Near and Middle East and cven the very existence of the British Empire.

The aggressive acts of Germany and Italy (the occupation of the rump state of Czechoslovakia, the annexation of Memel and the invasion of Albania) forced the British government on the eve of the Second World War to activate its policy on the Balkan Peninsula; thus establishing there certain strongholds meant to cut off Germany's route to the Mediterranean and the British colonial possessions should this prove necessary.

There has not hitherto been any special historical investigation exclusively devoted to the Turco-British relations on the eve of the Second World War. Numerous features of these relations have remained obscure waiting for the historian's torchlight to illuminate them. Some works of history dealing with the wider aspects of international relations in the years between 1936 and 1939 and studies on the foreign policies of Turkey and Britain in the same period survey only separate moments of the relations between the two countries. They examine mainly isolated facets of the foreign policies of the great powers in the Mediterranean and their struggle to draw Turkey within one or other of the contesting groups.

Turkish historians have rather tended to show greater interest in earlier periods of history, when the Turkish nation played a more crucial role on a world scale. The collective work by a group of prominent Turkish historians, Olaylarla Türk Dıs Politikası: $1919-1965$ (Turkish Foreign Policy with Events: 1919-1965), ${ }^{1}$ reflects standard Turkish historiography on a number of questions pertinent to the foreign policy of the country and, from this point of view, presents considerable interest despite its absence of footnotes and an index at the end. Another reference work for its authoritative assessments is Montrö ve Savaş Oncesi Yıllart: 1935-1939 (Montreux and Pre-War Years: 1935-1939), ${ }^{2}$ a publication of the Directorate General of Research and Policy Planning, Ministry of Foreign Affairs of the Republic of Turkey. Although quite short (only 247 pages), it is very useful for the

${ }^{1}$ M. Gönlübol, et.al., Olaylarla Türk Dı̨ Politikası: 1919-1965 (Turkish Foreign Policy with Events: 1919-1965), Ankara, 1969.

2Montrö ve Savaş Öncesi Yılları: 1935-1939 (Montreux and Pre-War Years: 1935-1939), Ankara, 1973. 
many documents printed throughout its text. Ataö ${ }^{3}$, who devoted a few chapters to the foreign policy of Turkey on the eve of the Second World War, lacks in diplomatic detail and documentary evidence. In part, this seems to be the result of less than exhaustive use of the available sources.

Vere-Hodge, ${ }^{4}$ the first among the non-Turkish scholars to address himself to the question of the foreign policy of the Republic of Turkey, did so at a time when the best available sources were contemporary newspapers. While the narrative is fairly accurate, he failed to analyse the events deeply. Based almost exclusively on British Foreign Office papers, Britain's pre-war rapprochement with Turkey and the concomitant cooling of Turkey's friendship with the Soviet Union are the subject of Zhivkova's 5 somewhat turgid and generally unsuccessful study of Turco-British relations between 1933 and 1939. Her discussion is marred by a rigid Marxist analysis which drives her to view the rivalry of the powers in the pre-war Balkans as a fight for markets a strange argument surely when the British only reluctantly, and then half-heartedly, accepted the necessity of economic conflict with Germany; and only then from political rather than economic necessity. In fact, it was the Balkan nations themselves which clamoured for 'exploitation' and the British businessmen who were reluctantly driven to accept the unwelcome necessity; their greatest source of reluctance being that incursions into the Balkan market might result in exactly the fight for markets which, if Zhivkova's analysis is correct, it was their purpose to wage the Marxist analysis of colonialism, in effect, placed on its head. Evans, ${ }^{6}$ who wrote later, made scant use of such evidence as there was, and confined his discussion, in the main, to the period before 1927. Without a driving argument and with no new data to import, Evans' work provides more of a reasoned summary of the existing literature than an innovative interpretation.

From the legions of memoirs published by Britain's pre-war statesmen, almost none concern themselves directly with Turco-British relations. Eden alone gives the subject any attention. ${ }^{7}$ From Turkish political leadership in our period, there is no voice. The diplomatic memoirs of Knatchbull-Hugessen, Massigli, and Von Papen, although equally interesting, are of limited use because none of the writers was in Ankara prior

${ }^{3}$ T. Ataöv, Turkish Foreign Policy: 1939-1945, Ankara, 1965.

${ }^{4}$ E. Vere-Hodge, Turkish Foreign Pollcy: 1918-1948, Anne-Masse, 1950.

5. Zhivkova, Anglo-Turkish Relations: 1933-1939, London, 1976.

${ }^{6}$ S. Evans, The Slow Rapprochement: Britain and Turkey in the age of Kemal Atatürk, London, 1982.

${ }^{7}$ A. Eden, The Eden Memoirs: Facing the Dictators, London, 1962. 
to the spring of 1939, and because, with the exception of Von Papen, they are more anecdotal than historical accounts. ${ }^{8}$

Few books on discussions of pre-war British diplomacy and strategy address themselves directly to the subject of Turco-British relations. The closest we have to an almost complete treatment of Turco-British relations on the eve of the Second World War is provided by Donald Cameron Watt in How War Came. ${ }^{9}$ In the extant historical literature on the period of 1936 1939 the meandering of Turco-British relations during the Montreux Conference on the Straits has been dealt with in greatest detail. Thus a special section to the Montreux negotiations is devoted in the Survey of International Affairs. ${ }^{10}$ But this publication cannot be adequate because it was written before most of the evidence was available.

The British policy of guarantees and the negotiations for a TurcoAnglo-French treaty for mutual aid have also been the subject of investigations by a number of authors. British historiography endeavours to present the 'policy of guarantees' as something significant and as a turning point in the policy of Neville Chamberlain's government. These changes in British policy are rated as a rejection of the policy of 'appeasement' and as a return to the policy of collective security. ${ }^{11}$ The myth of some diplomatic revolution, fostered by the British and Western press and by the writings of many authors and politicians has not been altogether discredited to this day. ${ }^{12}$ However, one of the best-known authorities on contemporary British history, Alan John Percivale Taylor, is something of a rarity: a British scholar assessing more realistically the policy of guarantees. He writes: 'Here was the turning-point in British policy. It was not meant as such: Chamberlain saw it as a change of emphasis, not a change of direction. The British still wanted a general settlement with Adolf Hitler, and they put obstacles in his way so that he would incline more readily to the agreement. ${ }^{13}$ Although some British historians criticise single instances in the activity of the Chamberlain's government and express their doubts about

${ }^{8} \mathrm{H}$. Knatchbull-Hugessen, Diplomat in Peace and War, London, 1949; R. Massigli, La Turquie devant la Guerre: Mission à Ankara 1939-1940, Paris, 1964; F. Von Papen, Memoirs, London, 1952.

${ }^{9}$ D. C. Watt, How War Came, London, 1989.

10 Survey of International Affairs (henceforth referred to as "S.I.A."), 1936, London, 1938, pp. 584-652.

${ }^{11}$ See, for instance, E. H. Carr, The Twenty Years' Crisis, London, 1951. 12 See, for example, L. Namier, Diplomatic Prelude: 1938-1939. London, 1948.

13 A. J. P. Taylor, The Origins of the Second World War, London, 1961, pp. 205-206. 
the effectiveness of the guarantees they do not reject the overall trend in British foreign policy. 14

Turkey, with its advantageous geographical position on the crossroads between East and West, had for centurics been the cause of fierce diplomatic contests and wars among the great powers. With the intensification of the conflicts between the European powers during the 1930s and the changes in the international setting after Hitler's advent to power, Turkey once again became a focal point wherein the interests of the Western democracies were entangled with those of Germany and Italy. Turkey's important strategic location and the heightened interest towards the possible political orientation of the Turkish government determined the active policy of the European powers towards it.

The cvolution of Turco-British relations in the late 1930s cannot be examined in isolation. They must be seen in the context of the whole international configuration between the two world wars. The links between Turkey and Britain to a great extent depended on the varying trends in the unfolding of the events in Europe, in the Balkans and in the Mediterranean region. Turkey's policy towards Britain and Britain's policy towards Turkey in turn affected and reflected the policy of many other countries. And precisely Turkey was the one country where the connections between Britain's interests in the Balkans and those in the Near East were most evident. The investigation of Turco-British relations during the period under scrutiny is most enlightening, as it enables us to outline rather thoroughly the complex international setting created in Europe and in the Balkans on the eve of the Second World War.

From a military, strategic and political point of view, Turkey was of exceptional interest to Britain. This characterised the approach of British diplomacy to Turkey, with whose help London hoped to retain its positions in the Near and Middle East and to secure its supremacy in the castern part of the Mediterranean. The Straits, which had been for centuries the natural core of the Turkish strategic importance, did still retain their paramount value for Britain's Mediterranean and colonial concerns. The status of the Turkish Straits had never ceased to be a matter of cardinal interest in the AngloItalian, Turco-Italian and espccially in the Turco-British relations. During the mid and late 1930s this question once more loomed large at the centre of Turco-British relations and to a large degree fashioned their character.

In dealing with the Straits' regime, Britain had never lost sight of its military and strategic interests. In some cases, this ran contrary to the national interests of Turkey and of the Black Sea states directly concerned

${ }^{14}$ Sec, for example, Taylor, The Origins; and Namier, Diplomatic Prelude. 
with the matter. As a Black Sca country, the Soviet Union could not remain indifferent to the regime of the Straits. Moreover, the attitude of Britain towards the Straits directly affected Turco-Soviet relations.

The invasion of Ethiopia by Italy in the fall of 1935 marked the beginning of a definitive closeness in Turco-British relations, which were to undergo a long process of development. This process ran parallel with a gradual carefully phased-out withdrawal of Turkey from the policy of firm cooperation with the Soviet Union. The rapprochement between the two countries in those years enabled Britain to consider Turkey as its safest link in the system of the Balkan countries on the eve of the Second World War.

One of the fundamental factors which during the late 1930s always directly moulded the development of Turco-British relations, was the apprehension about the aggressive policy of Italy. Turkey and Britain viewed the bellicose and thoughtlessly adventurous policy of Benito Mussolini as a danger threatening both the national interests of Turkey and the colonial interests of Britain. The Anglo-Italian and Turco-Italian conflicts in the Mediterranean region facilitated and accelerated the rapprochement between Turkey and Britain which progressed with particularly quick strides after the Italo-Ethiopian war.

The overall British policy in the late 1930s also indisputably lcft its mark on the political line taken by the British government towards Turkey. This in turn directly influenced Turkey's approach to Britain and to a considerable intent conditioned Turkey's part and place in international relations. That is why the question of Britain's policy towards Turkey and the foreign political orientation of the Turkish government on the eve of the Second World War is indeed complex.

In this paper it is hoped to retrace the successive stages in the development of Turco-British relations during the late 1930s and to bring forward the reasons, influences and factors which caused and speeded up the rapprochement between the two countries during that period. The British policy of guarantees and the efforts of Britain to form a Balkan anti-Hitlerite coalition under its own aegis and this is a question both complicated and controversial will be hereby examined in relation to Turkey's place and part in these plans.

Although the main theme of this survey centres on the period immediately preceding the Second World War, it has also proved necessary to cover some moments from the period after the outbreak of the war in order to reach the signing of the Turco-Anglo-French Tripartite Alliance Treaty of 19 October 1939. In the historical disquisitions on the Turco-British relations during the late 1930 s, this treaty is usually given preferential treatment. Both Turkish and British historiographies strive to unravel its fundamental reasons 
and try to pinpoint the aims pursued by Britain and France with the signing of the said document in symmetry with the motives of the Turkish govemment to abandon the policy of neutrality and join one of the contesting groups. The importance of such uncovering of the goals of the Turco-AngloFrench treaty far transcends the mere clarification of the political trends at the root of the policy of Britain and France towards Turkey and the Balkan countries. It offers a welcome possibility to present a clearer and fuller picture of the intricate international situation in Europe on the eve of the war.

In a major policy speech on 18 March 1934, Mussolini announced his ambitions in Asia and the Near East. This announcement came to Turkey as a rude reminder that, in spite of the Turco-Italian Treaty of Neutrality, Reconciliation and Judicial Settlement signed on 30 May 1928 and renewed in 1932, Italy had not abandoned those ambitions in southwestern Anatolia which had found expression in the Saint-Jean-de-Maurienne Agreement of 17 April 1917 and had shown new signs of life in December 1925, when Mussolini had threatened to invade the Mediterranean shores of the Asia Minor if Turkey went to war over the Mosul dispute. Turkey was scarcely comforted by the assurances of the Italian government, in answer to its anxious inquiries, that Mussolini's specch did not refer to Turkey, since he regarded Turkey as a European power. ${ }^{15}$

The Italian aggression in Ethiopia on 3 October 1935 gave Turkey additional reason to reflect on the sincerity of Mussolini's declaration in 1934 that 'the historic objectives of Italy are in Asia and Africa' and the fortifications of the island of Leros in the Dodecanese suggested that, when once Italy had digested its African meal, it might scek fresh morsels to satisfy its growing appetite in Asia. Shortly after the commencement of hostilities, the first Turkish chargé d'affaires to Ethiopia since 1914 and the first Turkish military attaché to this country cver, arrived in Addis Ababa. In addition, a Turkish soldicr-of-fortune, Vehip Paşa, was employed by the Ethiopian army as an adviser to its southern forces in a semi-official capacity. 16

On 7 October, reacting strongly to news of the Italian invasion, Turkish Foreign Minister Tevfik Rüştï Aras told Sir Percy Loraine, the British ambassador at Ankara, that Turkey could be expected to stand by its allies, its obligations and collective security and would follow Britain to the last ditch in defence of the Covenant of the League of Nations. Soon after the Italian attack on Ethiopia the League of Nations Assembly established a coordination committee for the imposition of sanctions. Turkey, with Poland,

\footnotetext{
15 S.I.A., 1936, pp. 601-602.

16 Ibid., 1935 , p. 83 .
} 
Soviet Union, Romania, Spain, Sweden and Yugoslavia represented the most irreconcilable element of what came to be known as the Committec of Eighteen. Turkey, as well, sat on the Co-ordination Committec, a more handy subcommittee of the Eighteen which acted as its directing body. The Eighteen considered three forms of economic action: a boycott of Italian goods, the embargo of essential imports, and the organisation of material support for Ethiopia. Its thoughts moving in the same direction as Britain's planners, on 14 October, the Co-ordination Committee agreed that member nations would provide support to League states acting in accordance with a League decision under Article 16 if attacked by Italy. Turkey was keen on sanctions and a 'Law for the Carrying Out of the Decision Taken by the League of Nations' enabling legislation to permit the application of sanctions was quickly passed through the Grand National Assembly with scarcely any dissent. ${ }^{17}$

Britain approached the Mediterranean powers France, Turkey, Greece and Yugoslavia with the question as to whether it could depend on their support in the event that the imposition of economic sanctions led to Italian attack. Turkey's answer was most encouraging of all. After consulting his Balkan allies, Aras formally advised London, Paris and Rome that Turkey would give immediate and total support to Britain in the event that it was attacked by Italy but would require a reciprocal assurance. The Turks, he told Loraine privately, understood their obligations under the Covenant in exactly the same way as did Britain. Aras said that in the event of Italian aggression Turkey would regard itself as engaged in a military alliance of which it accepts fully the responsibility, dangers and consequences. Loraine thought this answer complete and unconditional acceptance of British thesis. ${ }^{18}$

British planning for war against Italy in the Mediterrancan continued through the winter of 1935-1936. Chiefs of Staff Subcommittee of the Committee of Imperial Defence noted the continuing exchange of assurances with the Balkan powers. Turkey continued to out-do the others in its encouraging response. It promised to provide anchorage and repair facilities in the Sea of Marmara and to allow Britain to establish a contraband control

${ }^{17}$ Foreign Office Papers, Public Record Office, London (henceforth referred to as "F.O."), 371/20091/272, Annual Report for 1935. Para. 116. Also Cabinet Orfice Papers (henceforth referred to as "CAB"), 24/257, CP 200(35), Export of Materials and Implements of War Co-ordination Committee, 27 October 1935. Moreover see Ahmet Sükrü Esmer, Turkey and the United Nations, New York, 1961, p. 40.

18 British Documents on Foreign Policy (henceforth referred to as "B.D.F.P."), Ser. 2, Vol. 15, No. 339 and 340, Loraine (Ankara) to F.O., 9 December 1935. 
centre to supervise Straits shipping. Even further, it promised the direct cooperation of the Turkish Navy and Air Force against the Dodecanese. ${ }^{19}$

Italy angered at the line Turkey was taking, threatened to renounce the Turco-Italian Treaty of Neutrality, Reconciliation and Judicial Settlement. Turkish actions were 'inconsistent with the engagements of the Turkish government under the treaty of friendship with Italy'. Turkey, however, maintained stoutly that it was doing no more than its duty as a member of the League of Nations, and denied that it had any intention of attacking Italy. Turkey further replied to the Italian protest by asking, through Fethi Okyar, its ambassador in London, if it could depend on British naval support in the event of Italian attack. Britain answered that 'His Majesty's government could be counted upon to do its duty'. It is notable that, while other of the smaller nations began to chaff at sanctions and the dangers they represented, Turkey was insistent that the League and its Covenant must stand as established. Ankara faithfully supported League action against the aggressors. 20

Undeterred by sanctions, Italy completed the conquest of Ethiopia by the spring of 1936 and thus made a serious alteration in the Middle EasternAfrican structure. This trend was accentuated by Hitler's unilateral violations of the Peace Treaty of Versailles, such as the rearmament of Germany announced in March 1935 and the remilitarisation of the Rhineland a year later. The European totalitarians were obviously on the move and diplomatic revisionism had given place to military action.

The general situation of Europe having changed politically and militarily, Turkey felt the need to remilitarise the Straits and thereby revise the Lausanne Peace Treaty of 24 July 1923. The motives behind this fecling were that the League of Nations had declined in consequence of German rearmament and Italian aggression in Ethiopia; Germany had remilitarised the Rhineland and there was no adequate provisions in the Lausanne Treaty guarantecing Turkish security in case of war. It contained no provision which permitted Turkey to take effective measures in the Straits in the face of an immediate threat. The emergence of ambitious Germany and Italy had led to an armaments race which upset the status quo to which the out-dated Lausanne Treaty was applicable. Italy had already bcgun to fortify the island of Leros which was so near the Turkish coast. 21

${ }^{19}$ CA B 53/26, COS 421 (JP), Defence of the Eastern Mediterranean and Middle East, 19 December 1935.

20 F.O. 371/954/28, Eden Minute, 7 January 1936. B.D.F.P., Ser. 2, Vol. 15. No. 438, Eden to Loraine (Ankara), 8 January 1936.

${ }^{21}$ F. C. Erkin, Les Relations Turco-Soviétiques et la Question des Détroits, Ankara, 1968, pp. 70-77. A. S. Esmer, 'The Straits: Crux of World Politics', Foreign Affairs, January 1947, p. 295. Also H. N. 
In view of the urgency to remilitarise the Straits, Turkey could have resorted to unilateral action, but it preferred an agreement through an international conference. Turkish leadership expected a more favourable reply to a request made in a lawful way, without undermining the League system. Moreover, Turkey would score a moral success of being the first state to use legal methods for the revision of a post-war treaty. On 10 April 1936, Aras, while addressing a meeting of the ruling Republican People's Party, referred to the government's decision to request the Lausanne signatories to meet to discuss the remilitarisation of the Straits. The Turkish note, addressed to the signatories of the Straits Convention, the Secretary-General of the League and Yugoslavia, pointed at the uncertainty which had gradually arisen in the Mediterranean, the tendency towards rearmament and the lack of guarantee for the security of the Straits. 22

With Italy's exception, the reactions to the Turkish note werc favourable. Britain had not only found the Turkish claim fully justified but was also in need to find new allics in the eastern Mediterranean, where Italy was challenging its interests. This also offered it an opportunity to pull Turkey away from the Soviet Union. Moreover, the Rhineland already militarised, the remilitarisation of the Straits could not serve as a precedent for Germany. The British support would also eliminate the remote possibility of a dissatisfied Turkey being driven into the political sphere of Germany once again. British government also used its good offices in supporting the Turkish case with the French government, urging that it was most desirable on grounds of general principle to give all reasonable encouragement to the procedure, adopted by the Turkish government, of proposing treaty revision by negotiation and agreement. Britain feared that Turkey's unilateral militarisation of the Straits would push it into common cause with Germany, Italy and Japan, all outside the orbit of Covenant defenders. The reaction in the London press to the Turkish note was the subject of favourable comment in the Turkish press, which also expressed satisfaction at the delicacy shown by Britain in sending a quick reply to the Turkish note, and in stating its readiness to discuss the question immediately, adding that the ties of friendship which were being daily strengthened between Turkey and Britain would form the most solid basis for the establishment of peace in the Mediterranean. 23

Howard, The Straits After the Montreux Convention', Foreign Affairs, October 1936, p. 200.

22 Ibid. For the text of the Turkish note see Documents on International Affairs (henceforth referred to as "D.I.A."), 1936, London, 1936, pp. 645-648.

23F.O. 371/20886/10426, Annual Report 193. Para.s 24 and 25. G. Ciano, Ciano's Diplomatic Papers, London, 1948, p. 4. Entry for 15 June 1936. Also S.I.A. 1936, pp. 608-610. 
The conference for revision met at Montreux on 22 June. Agreement was reached on the last day 20 July 1936 . There were vital differences between the Turkish and British theses. Britain, however, was prepared to waive a number of important claims in return for a full understanding with the Turks. At the Montreux Conference, the closest co-operation was maintained between the Turkish and British delegations. Britain's need for the Turkish support led to the acceptance of the Turkish draft as the basis of discussion. Britain when the divergence of its claims from those of the Turks became clear upon the submission of the British draft finally showed its Turkish support by agreeing to full Turkish remilitarisation and after some discussion to the total suspension of the International Commission. The British and French surrender over this latter point vital to the pride of the Turks paved the way for a future understanding between the three countries. The final draft approved unanimously was a clear victory for Turkey. 24

The signature of the Montreux Straits Convention was the signal for remarkable manifestations of joy throughout Turkey. The Turkish troops, who reoccupied the Istanbul and Çanakkale zones during the night of 20 and the morning of 21 July, were greeted with garlands and streamers, and the Turkish flect was met by cheering crowds. The signature itself was announced by broadcasts throughout the country, and was celebrated with flags, illuminations, speeches and torchlight processions. The press was enthusiastic, and special tributes were paid to the gentlemanly manner in which British diplomacy had worked in a question of vital importance to Turkey. According to Loraine, Atatürk informed him that he regarded the outcome of the conference as a 'common success' for Turkey and Britain, and that he rejoiced at the friendly understanding that characterised the relations between the two governments. Cordial greetings were exchanged between Aras and his British counterpart, Anthony Eden. 25

The Turkish press, after the successful conclusion of the conference took on a markedly more Anglophile tone; an immediate effect of the improved relations was the giving of several important consignments featuring in the Turkish rearmament and industrialisation plan to British companies, the most notable being the assignment of refortification of the Straits to Messrs. Vickers. These actions not only proved diminished distrust

${ }^{24}$ Ibid., 1011/73, Loraine (Ankara) to the King, 15 July 1936. CAB 28/85. Cab. 52 (36), 15 July 1936. Also Howard, The Straits, p. 202.

25 Ibid., 20886/10426, Annual Report 1936. Para. 29. Review of Turkish press comments in Ayın Tarihl (News of the Month), Turkish Government Press, Broadcasting and Tourism Office Publication, Ankara, 1936, pp. 113117. 
of British intentions; but a preference on the part of the Turks for exposing their defence areas to British rather than to German eyes. ${ }^{26}$

Britain began to reshape its polite but non-committal attitude of former ycars towards the Turks, especially in the ficld of commercial relations. There had always been difficulties barring any extensive trading between the two countries, but from 1935 onwards an attempt was made by both governments to diminish these: a clearing agrecment was signed on 2 September 1936 with the express purpose of increasing the trade volume and the following year saw an exchange of notes upon the possibilitics of further increasing of inter-trade. This limited trade drive on the part of Britain was mainly political in aim, its object being to relicve the Turks from their growing dependence upon German economy. 27

Along with improved trade relations after Montreux, the deep-rooted anti-British fecling that still prevailed in many influential Turkish circles began to give way to more friendly sentiments. An important stimulus was given to this new phase of Turco-British relations when on 3 September 1936 King Edward VIII, travelling as the Duke of Lancaster, arrived off Gökçeada in the steam yacht Nahlin to pay a private visit to the Çanakkale Peninsula and to Istanbul. He was met outside the Straits by two Turkish destroyers, Adatepe and Kocatepe. Escorted by these, the yacht proceeded to visit the battlefields and cemeteries on the peninsula. The Nahlin arrived in Istanbul in the morning of 4 September. The King, on landing, was greeted by the President, with whom he drove to the British Consulate-General building in Tepebaşy, where he received Atatürk's visit. A return personal visit to Atatürk at the Dolmabahçe Palace was paid by the King later in the day. While in Turkey, the King met most of the leading Turkish statesmen. It was a mark of the importance of this visit for the Turks that his Aide during the visit was General Fahrettin Altay, the general officer commanding the 4th Corps at Gallipoli in 1915. Altay, in 1936, was the second most highly rated soldier in the Turkish army. King's visit was an entirely unexpected honour for the Turkish government; but in spite of this Ataturk received him with great courtesy and the most cordial personal relations were established in the short course of his stay in Turkey. The King remained in Istanbul until 6 September, on which day he left for Vienna in the Turkish presidential train which had been placed at his disposal. 28

${ }^{26}$ E. Monroe, The Mediterranean in Polltics, New York, 1938, p. 215.

27F.O. 371/20886/10426, Annual Report 1936, Para.s 55 and 60.

${ }^{28}$ Ibid., 1011/73, Loraine (Ankara) to the King, 28 November 1936. Ibid., 91. Loraine (Ankara) to Wigram, 5 December 1936. Also The Duke of Windsor, A King's Story, New York, 1951, pp. 308-310. Moreover see F. Altay, Imparatorluktan Cumhuriyete (From Empire to Republic), Edited by Taylan Sorgun, Istanbul, 1998, pp. 483-493. 
Hitherto Britain had still been considered as a traditional foc in Turkey. This visit brought about a psychological change in the mental attitude of the Turkish people towards Britain. The occasion, and the exceptional feeling of interest for the person of King Edward which was instantly engendered among the general public, had the effect of popularising in the space of a few days among all segments of the Turkish population the newly reformed friendship with Britain which till then had been the affair rather of governments than of peoples. And according to the Annual Report of the British Embassy on Turkey for the year 1936, it seemed as though a few hours had sufficed to efface from the Turkish mind, 'in a manner far more reminiscent of the Arabian Nights Entertainment than of the hard, prosaic realities of the 20th century, the bitter memorics of Turco-British hostilities and antagonisms between 1914 and 1923.' A visit from the British monarch was looked upon as a great compliment particularly as some British writers had erroneously labelled Atatürk as a 'dictator' and had often mentioned deprecatingly of a President who was regarded by his compatriots in Turkey with the deepest respect and admiration. King's visit, coming as it did just after the Montreux settlement, carried the Turco-British understanding established at the conference table onto a warmer and more personal plane. This visit evoked immense enthusiasm amongst all classes of the Turkish population, and the mutual friendship took a further step forward. 29

There was a tendency in the Turkish public to give King Edward's visit to Turkey a significance of far-reaching political importance. Whatever the relative point of view might be, the fact deserved attention that the relations between Turkey and Britain had improved to the extent not only of rendering the royal visit possible, but also of making it the opportunity for the manifestation of cordial pro-British feelings. Ever since the Turkish Republic was founded, personalities, crowned and uncrowned, and representative of the nations to which they belonged, had come and found in Turkey a welcome consistent with the best Turkish traditions; but never had the man-in-the-street expressed so much joy mingled with curiosity at sceing the Sovereign of the British Empire. Despite the requirements of official incognito, the welcome offered to King Edward really was a kingly one. ${ }^{30}$

The King's visit was followed by a much publicised courtesy call of the Turkish flect to Malta in November 1936. In 1929, units of the British Mediterranean fleet had paid an official visit to Turkey. This visit had never been returned, and the question of its return in 1935 had been deferred owing to the Ethiopian crisis. Early in August 1936, however, the British Admiralty expressed a wish that normal visits between the British and

${ }^{29}$ Ibid., 424/280. E4867/1373/44, Eden to Loraine (Ankara), 10 September 1936; and E5307/1373/44, Loraine (Ankara) to Eden, 21 September 1936.

$30_{\text {I bid. }}$. 
Turkish fleets should be resumed, provided that no visit should be paid by British ships to Turkish ports until the 1929 visit had been returned. The Turkish government, on being approached, readily accepted a suggestion that the resumption of visits could be usefully and opportunely inaugurated by a visit by the Turkish flect to Malta, and the date of the visit was duly fixed for 20-26 November. The preparations for this visit, and the visit itself, produced a further demonstration of cordiality. When the visit of the Turkish fleet under the command of Vice-Admiral Sükrü Okan, consisting of the battle cruiser Yavuz, four destroyers, four submarines and a submarine depot-ship, took place as scheduled, Admiral Sir Dudley Moore, Commander-in-Chief of the British naval forces in the Mediterranean, judged the event as unqualified success. Atatürk was also pleased with the results of the visit. In Ankara, Loraine was having supper in the Ankara Palace Hotel with Aras and Celal Bayar, Minister of Economics, when Ataturk appeared with his entourage. Atatürk read to the diners the transcript of Pound's welcoming speech to the Turkish squadron. This was the first visit paid to a foreign country by a Turkish fleet since the war. ${ }^{31}$

For the first time since 1918 the Turkish fleet steamed through the Dardanelles into the Mediterranean. What was more, the vessels paid a visit to Malta, the premier British naval base in the Mediterranean. This visit was the culminating event of a long series of moves which had converted Turkey from the enemy of the Great War years to a staunch friend of Britain. The change was a notable one, of great importance to the security of both Turkey and Britain.

In Rome, Mussolini was terrifically angry at the visit of the Turkish fleet to Malta especially coming so soon after Edward VIII had pointedly excluded Italy from his Mediterranean cruise. Hitler also appeared to have been annoyed at the growing Turco-British friendship. In January 1937, Aras told Loraine that Hitler had invited the Turkish fleet to make a visit to Kicl as a 'grandiose manifestation of Turco-German friendship'. The Turks ignored the offer. 32

In January 1937, Turkey began to endeavour to mend its fences with Italy. On 3 February, Aras went to visit Count Galeazzo Ciano in Milan. Reconciliation does indeed seem to have been the Turkish intention. While Turkey welcomed the opportunity of having itself smoother and more cordial relations with Italy, and was less apprehensive of a clash with Italy in view of the progressive strengthening of Turkish armaments, the query marks it put against ulterior Italian ambitions had not been removed and its attitude remained watchful. Aras' trip to Milan had been preceded by a month of the

31 Ibid., 1011/39, Loraine (Ankara) to Oliphant, 24 November 1936.

32Ibid., 282, E264/264/44, Loraine (Ankara) to Eden, 12 January 1937. 
Anglo-Italian conversations leading to the Gentlemen's Agreement of 2 January 1937. In going to Milan, Aras was not so much moving away from Britain as rushing to stay parallel with British policy as it manoeuvred towards the appeasement of Italy. Turkey was less concerned with achieving rapprochement with Italy, then with avoiding the consequences of an exclusively Anglo-Italian accommodation. Returning from his mecting with Ciano, Aras paused long enough in Belgrade to issue a joint communiqué with his Yugoslav counterpart Milan Stojadinovic saluting the Gentlemen's Agreement with satisfaction. Two weeks later, on 18 February, the Permanent Council of the Balkan Entente issued a communiqué supportive of the British initiative. ${ }^{33}$

Aras reassured the British of Turkish fidelity. He said: 'Now that the basic coincidence of Turkey's interests with those of Britain was established and the decision had been taken by the Turkish government to mould its local policy in harmony with Britain's world policy, Turkey was realising that the possibilities for good, in every way of co-operation with Britain were far greater even than it had dreamed them to be'. If there were war, Turkey would fight on the side of Britain'. ${ }^{34}$ Further, on 6 April, Aras told Loraine that Turkey was most emphatically not negotiating with the Italians 'but that every now and then he discussed the general situation in a friendly tone' with them. One of the things, Aras told, that he discussed with Ciano, was how to stop Italy being so disagrecable to Britain and make an effort really to improve Anglo-Italian relations. Loraine wrote that he, himself, had 'never detected any desire on the part of the Turks to widen the scope of their friendship with Italy'. ${ }^{35}$ Given Ciano's account of his discussion with Aras, it seems certain that the Turks were not contemplating anything more drastic than a mending of bridges.

The President of the Turkish Republic was represented at the Coronation of King George VI by the Prime Minister Ismet Inönü. Both İnönü and the Turkish of ficials who accompanied him declared themselves as highly gratified with their reception in Britain. This visit further advanced the mutual friendship. In an address to the Grand National Assembly on 14 June 1937 after his return, Inönü referred in glowing terms to the 'utmost

${ }^{33}$ B.D.F.P., Ser. 2, Vol. 18, No. 170, Loraine (Ankara) to F.O., 12 February 1937; and Ciano (1948), pp. 93-95. Entry for 4 February 1937. Also S.I.A. (1936), pp. 652-666; and D.I.A. (1936), pp. 87 and 349. Moreover see the leading article by Falih Rıfkı Atay in Ulus of 1 February 1937.

34 F.O. 371/954/28, Loraine (Ankara) to Eden, 24 February 1937.

35 B.D.F.P., Ser. 2, Vol. 18, No. 377, Loraine (Ankara) to Eden, 6 April 1937. 
cordiality' he had observed in the public as well as the official circles. ${ }^{36}$ The Turkish government sent a destroyer to participate in the naval review held in connection with the Coronation celebrations. Both in 1936 and 1937 Inönü also attended Ascot, and would have gone in 1938 if he had remained in office. ${ }^{37}$

The benevolent attitude of the British government during the Montreux conference helped to increase the pro-British feclings in Turkey and by 1937 a seemingly well-established Anglophobia and the bogcy of 'intrigues of the British intelligence service' almost disappeared from Turkish minds. ${ }^{38}$ In the months after Montreux, the Turks had begun to try to convince the British into some formal bilateral arrangement. Britain, on its part, feared that the Turks might use a British alignment to lead it into conflict and commitment. An alignment with Turkey, if the Turks chose to make use of it in an unacceptable fashion, might become what London apprehended most: an uncongenial commitment, a possible provocation, and an obstacle to broader pacification. As Britain moved towards accommodation with Italy, it did not wish to be saddled with any irreconcilable Turkey. Unwilling to permit Turco-British relations to go further in the direction they had been travelling, but not anxious for them to retum from whence they had come, Britain increasingly resorted to informal means to buttress its relationship with Turkey. The Turks, for their part, made an offer of alliance to the British government in the latter half of 1936; the latter declined in the politest of the possible terms stating that the time for alliance did not yet seem to be opportune. British diplomacy was, however, very anxious not to repel Turkish advances and the possibilities of closer understanding were being fully explored by both governments. ${ }^{39}$

It would not be too much to say, indecd, that Britain was on more cordial terms with Turkey than at any period in the history of the two countries, with the result that Turkey now implicitly trusted the word of Britain. A happy symptom of this trust was visible in the choice on 13 November 1936 by the Turkish government of the firm of Sir Alexander Gibb as its consulting engineer and technical adviser. Such advisers existed in a multitude of nations: there were many, in fact, who canvassed their claims

36 Ismet Inönü'nün TВMM ve CHP Kurultaylarında Söylev ve Demeçleri (1919-1946) [Ismet Inöna's Speeches and Statements in the Grand National Assembly of Turkey and in the Conventions of the Republican People's Party (1919-1946)], Istanbul, 1946, p. 323. Speech of 14 June 1937.

37F.O., 371/1011/92, Loraine (Ankara) to Hardinge, 26 April 1938.

38 A. Kılıç, Turkey and the World, Washington, 1959, p. 61.

${ }^{39}$ F.O., 371/424/282, E824/188/444, Loraine (Ankara) to Eden, 29 January 1937. CAB 51/4, Cab. 61st Meeting, 17 December 1936. 
for the privilege. But the Turks were resolved that for this extremely responsible post a Briton alone was suitable. As it was, an agreement was reached in record time. Soon Sir Alexander Gibb's representatives were in Turkey, beginning with an improvement of the harbours of Istanbul. Much work in other parts of Turkey lay before them. So would private British enterprise buttress the official policy of Turco-British friendship. On 2 December 1936, an agreement was concluded between the Turkish government and the Messrs. Brassert for the construction of the Ereğli iron and steel plant. The whole transaction, involving close on threc million pounds, was guaranteed by the British government through the Export Credits Guarantee Department. 40

It was fortunate for the prospects of the Turco-British relationship, if not for British foreign policy in general, that Britain's movement back towards Italy, by the summer, was arrested and reversed by the reaction of the powers to the outbreak of civil war in Spain on 18 July 1936. In the eastern Mediterranean, the Spanish civil war made little impact until sinkings by unidentified submarines began in August 1937. Most alarming for Turkey, these submarines were operating inside the Straits themselves. This seemed to highlight Turkish vulnerability while raising the possibility of dangerous international complications for a Turkey only just restored to full sovereignty over the Straits. ${ }^{41}$

The Turkish government lost no time in informing diplomatic missions at Ankara that any submarine found so acting in violation of the Straits Convention and international law would be captured or, if necessary, destroyed, in the event of it failing to surrender immediately. The continuing acts of piracy committed on merchant shipping by submarines in the Mediterranean led the British and French governments and certain other powers in September to convene an urgent meeting of Mediterranean in order to deal with the situation of grave insecurity which had arisen. At the Nyon conference of 14 Scptember 1937, Turkey gave loyal support to Britain and France in their defence of international shipping against attacks by unknown and most probably Italian submarines. The signatories, which were Britain, France, Soviet Union, Turkey, Greece, Yugoslavia, Romania, Bulgaria and Egypt, agreed that any submarine which attacked a ship in a manner contrary to the rules of international law referred to in the International Treaty for the Limitation and Reduction of Naval Armaments signed in London on 25 March 1936 should be counter-attacked and, if possible, destroyed. In order to facilitate the putting into force of the above arrangements, the British and

40 Ibid.

${ }^{41}$ S.I.A., 1937-II, p. 342. 
French flects were to operate in the Mediterrancan up to the entrance of the Dardanclles. $^{42}$

The Turks were responsible for providing bases for patrolling vessels in the Aegean. They were also responsible for patrolling the Turkish territorial waters and the Dardanelles. From 17 September, the Turks refused port facilities to Italian vessels. On 18 September, Numan Menemencioğlu, the Secretary-General of the Turkish Ministry of Foreign Affairs, introduced the Nyon Agreement to the Grand National Assembly. The aim of the agreement, he told the deputies, was to prevent a war which could only be a catastrophe. He called on those 'great powers which still remained outside the arrangement to adhere'. 43 On 28 September, Inönü announced his resignation 'for reasons of health' from the Premiership. One rumour was that he had opposed Atatürk's policy at Nyon as too confrontational. ${ }^{44}$

The antisubmarine patrols were a startling success. Submarine piracy quickly disappeared; not least because on 14 September Mussolini had ordered a stop to sinkings. On 30 September, not linking its position on the outside of something frighteningly like a Mediterranean pact, Italy adhered to the agreement and took over responsibility for patrols in the Adriatic. ${ }^{45} \mathrm{Nyon}$, if nothing else, drove the Turks and British closer together by associating them in what was, in effect, an informal alliance against Italy. In addition, the procedure adopted at Nyon of formally associating the smaller powers with the actions of the great had an excellent effect on Turco-British relations. Winston Churchill later wrote that under the 'almost effusively friendly lead of Turkey' the attitude of the small Mediterranean powers had been satisfactory. 46

Turco-British friendship was now a living reality, which by clever diplomacy could be made to extend to countries with whom either Turkish

42 Documents Diplomatiques Français (henceforth referred to as "D.D.F."), Ser. 2, Vol. 6, No.s 328, 339 and 351, Ponsot (Ankara) to Delbos, 18 and 24 August 1937.

${ }^{43}$ F.O., 371/424/282, W17959/16618/41, Morgan (Ankara) to Chamberlain, 21 September 1937.

${ }^{44}$ Bulletin of International Affairs. Vol. 14, No. 7, 2 October 1937, p. 45. It was said that Inönü had counselled a more cautious approach in the matter than was actually followed. How different were the differences between the two men was never reliably confirmed. It is an interesting story, yet one that still remains to some extent hidden in Turkish diplomatic archives of the Republican era. These unfortunately have not been classified yet and opened to researchers.

45 B.D.F.P., Ser. 2, Vol. 19. No. 214. F.O. to Phipps (Paris), 30 September 1937.

${ }^{46}$ W. Churchill, The Gathering Storm, Boston, 1948, p. 246. 
and British relations might hitherto not had been all that they might be. This friendship was, indeed, one of the corner-stones in international politics, based firmly on identity of interests and mutual admiration. It could be made even more fruitful than it now was, standing model as it was of how former enemies might become fast friends.

The trend of Turkish general policy to inclinc more and more determinedly towards the closest terms of friendship with Britain was also demonstrated by Turkey's attitude towards Germany. Aras remarked to Eden at Geneva in January 1937 that Turkey must never again make the mistake of finding itself ranged in war on the wrong side, that is, against Britain. 47 Atatürk told the British ambassador in Ankara in unequivocal terms his determination that Turkey should never allow itself to be dragged in the political wake of Germany as it had happened before. In the evening of 29 October 1937 during the celcbration reception of the fourtcenth anniversary of the proclamation of the Turkish Republic, Ataturk had the first intimation of the coming Turco-British agreement. The British ambassador was the only diplomat invited by Atatürk to sit beside him from eleven o'clock in the evening throughout the night until ten o'clock next morning, while the German ambassador was only granted a few passing moments. Turkey had experienced a German alliance and it wanted no repetition of that. ${ }^{48}$

In the economic sphere, the co-operation inaugurated in 1936 by the signature of the Brassert contract was continued and in certain respects developed. The foundation-stone of the iron and steel works which Messrs. Brassert was constructing at Karabük had been laid on 3 April 1937. The occasion seemed in the eyes of most, Turks and foreigners alike, to be mainly a demonstration of Turco-British friendship. ${ }^{49}$

Ever since the days when Sir George Clark was ambassador to Turkey, Turco-British relations had steadily improved, and, too, from that time, each country had been fortunate in their representatives in the respective capitals. Each ambassador was a man of renown and distinction. A not unimportant part was played in the improvement of Turco-British relations by the British ambassador Loraine at Ankara. During his term of duty between 1934 to 1939 Loraine apparently became a personal friend of Atatürk and this rapport between the British ambassador and the Turkish President became something

\footnotetext{
47F.O. 371/954/28, Eden (Geneva) to Foreign Office, 26 January 1937.

48 Public Record Office, London (henceforth referred to as "PRO"), Loraine's Private Papers. Personal and confidential letter from Sir Percy Loraine to Anthony Eden, 8 May 1938.

49 Ib id.
} 
of a legend. ${ }^{50}$ Britain's ambassador to Turkey during the Second World War, Sir Hugh Knatchbull-Hugessen, claims in his autobiography that an ability to sit all night through in drinking and card-playing sessions with the head of state was a 'requirement' for holding a diplomatic posting in Turkey. ${ }^{51}$ It was a widely held belief widely held, that is to say in the British Foreign Office that the Turco-British rapprochement in the second half of the 1930s had been made during Loraine's nocturnal tête-à-têtes with Atatürk. ${ }^{52}$

Knatchbull-Hugessen gives a prominent place to the view that the reorientation of Turkey towards the policy of rapprochement and friendship with Britain was a personal decision and an individual act of Atatürk. According to the British ambassador, for Ankara's part, this had been a long process of careful deliberation and the decision for closer links with Britain had been in tune with the real national interest of Turkey. To that effect the statesmanship of Atatürk was indisputable. ${ }^{53}$

Considering the high degree of personal involvement by Atatürk in the affairs of his country, the above accounts probably accurately reflect the truth. It was, however, very unusual for the Turkish President to meet foreign representatives on a personal basis and so this may be taken as an indication of the importance he gave to good relations with Britain. Meanwhile, another sign of Atatürk's early interest in developing better relations with Britain was the appointment of his close friend Fethi Okyar one of the former Prime Ministers of Turkey as ambassador to London in 1934. Okyar was a strong Anglophile who had been to London in 1921, while Minister of the Interior, in the Ankara government, to attend to negotiate a compromise peace with Britain.

${ }^{50} \mathrm{It}$ is generally thought that Loraine achieved his greatest professional success at Ankara, thanks to his sympathy with the new Turkey and to his close relationship with Atatürk. For a general description of the role and activities of Loraine in Turkey see his biography by G. Waterfield, Professional Diplomat: Sir Percy Loraine, London, 1937, pp. 198 228.

${ }^{51}$ Knatchbull-Hugessen, Diplomat in Peace in Peace and War, p. 129.

52 See, for instance, F.O. 371/23060, C3538/3356/18, Minute by Cadogan, 18 March 1939. For a similar view of Loraine's friendship with Ataturk see J. Colville, The Fringes of Power: Downing Street Diaries 1939. 1945, Vol. 1, London, 1985, p. 13, where it is mentioned that the British ambassador. Sir Percy Loraine, was able to stay up night after night playing cards and drinking with Atatürk and becoming, in the process, an intimate friend and counsellor. Colville was the Private Secretary to the British Prime Minister Neville Chamberlain.

53 Knatchbull-Hugessen, Diplomat in Peace and War, pp. 144-145. 
Turkey's distrust of the totalitarian states became deeper during 1938 . It was not fond of the policy of the Rome-Berlin Axis; it did not acquit Italy of designs in the eastern Mediterranean; it was impressed with the grave danger that Germany's advent to the shores, whether of the Black Sea or the Aegean Sea, would create. The annexation of Austria in March and the dismemberment of Czechoslovakia in September, and the increased imminence of direct danger which they represented, stiffened Turkey's resolve to do all in its power to co-operate with Britain in adverting the danger and, if the need came, to join Britain in fighting it. There was, naturally, recognition that the balance of armed strength had moved against the British and its Western friends; but there was no sign of Turkey faltering or flinching on that account in its friendship or its policies. During 1938 it became increasingly evident that in the event of an armed conflict in Europe Turkish sympathies would be strongly on the side of Britain. A highly important statement was made by Aras at Geneva in September to the Egyptian and Iraqi delegates to the League of Nations Assembly; to them, without in any way pledging his government, he expressed his personal opinion that, if the neutrality of either country was violated by a power at war with Britain, Turkey would go to the assistance of that country. In recounting this to Loraine, Aras added that he was quite centain that in the circumstances Turkey would take military action; and he believed that it would, if necessary, be able to enlist the armed aid of the other three members of the Balkan Entente. 54

The outstanding event of the year 1938 in Turco-British relations as a whole was, without doubt, the signature in London on 27 May of the Guarantec Agrecment and the Armaments Credit Agreement. By the former a credit of ten million pounds was granted for the industrial development of Turkey and by the latter a credit of six million pounds, to be expended on the purchase of armaments in Britain (3,500,000 pounds for the navy, 1,500,000 pounds for coast defence and one million pounds for aircraft). The effect of these agreements was extremely valuable in the political sphere. The increasing intimacy of Turco-British relations had made it almost imperative that some signed expression of British interest in Turkey should be forthcoming. At all times Loraine had urged that the most acceptable and useful manifestation of this interest would be in the economic domain; and the Turkish govemment itsclf made no secret of its strong desire to receive assistance in the manner finally arranged. As well as further strengthening the growing friendship between Ankara and London, this loan eliminated the necessity of Turkey depending on Germany for over one-half of its trade. 55

54F.O. 371/23301/10426, Annual Report 1938, Para.s 5, 7 and 55.

55 Ibid., 21921, E/3164/67/44, Foreign Office to Loraine (Ankara), 27 May 1938. CAB 93/23 (8), Minutes, 27 May 1938. See also Documents on German Foreign Pollcy (henceforth referred to as "D.G.F.P."), D.V., 
The ultimate success of the long and often difficult negotiations, which were linked up with further negotiations for a revision of the Trade and Clearing Agreement, was hailed with the greatest satisfaction by all circles in Turkey from the President downwards; Aras characterised the agreements as a striking proof of British friendship and confidence towards Turkey. No matter what happens, never will we be found in a camp opposing Britain', Aras said to Joseph Levy the Near East correspondent of The New York Times on 21 July 1938. 'Our friendship with Britain is one of confidence and solidarity', he told. Imagine (remarked Aras) here is a country granting us a loan of sixteen million pounds, an important part of which is for armaments, without asking anything in return. Any other country would have demanded all sorts of privileges in times of peace and particularly in case of war, but Britain asked nothing. It trusted us as it would be a real friend. Britain showed it had faith in us. We will show it that this faith is not misplaced. The Turks are convinced that siding with Britain at any time means playing safe, Aras went on. 'Britain may lose a battle, but never a war. It has money, a navy and character. When a nation possesses these three important factors it is always certain of being victorious'.

The passing of Atatuirk on 10 November 1938 and the change of leadership did not imply an alteration in policy in Turkey. The course established by Alatürk for Turkey was plain and, given existing circumstances, irrevocable; it commended itself to the whole nation, who were alike constituents and full supporters. Inönü, the new President, was indeed a true statesman with a most illustrious record of service for his country. It would be correct to say that no Turk understood better the aims of the late President than Inönü who was his Premier for some fourtecn years. Among those whom Inönü omitted from his government was Aras. But in the existing flow of Turkish life shift of personnel signified little.

The replacement as Forcign Minister of Aras by Süukrü Saraçoğlu betokened no change in the intimacy of Turco-British relations. A specific assurance that Turkey's foreign policy remained unaltered was given to Loraine on the occasion of his first official interview with Saraçoğlu; the Turkish ambassador in London, upon instructions from the new President, spoke at the Forcign Office in a similar sense, and similar assurances were given spontaneously to Loraine by the new President, on the day after his election, in the course of a private audience. 56

Until spring 1939, Turco-British relations remained the story of a Turkish attempt to bring the British to some more formal relationship, and

96/107691-96, No. 545, pp. 128-132, Memorandum by the Deputy Director of the Economic Policy Department (Clodius), 29 June 1938.

56 Ibld., 10426, Annual Report 1938, Para. 54. 
of a British effort to so arrange their greater politics that such a relationship would be unnecessary. While fully apprised of Turkey's importance to the British position in the castern Mediterranean and the Near East, and in war planning against Italy, London remained reluctant to commit itself to anything which might antagonise Italy. Turkey was an important consideration but a consideration in a case which London preferred not to consider. The replacement of a general policy of drift by one of vigorous appeasement, when Neville Chamberlain succeeded Stanley Baldwin as Prime Minister on 28 May 1937, and the resignation of Anthony Eden after a foreign policy disagreement with the new Premier, increased the basic British reluctance to do anything remotely confrontational in the Meditcrrancan, which included, in London's doctrine, making any kind of combination with Turkey. ${ }^{57}$

Chamberlain's interest was confined primarily to the great questions Germany, Italy and Japan but it was incvitable that his activities here would have an impact on associated questions. A question strongly influenced by Chamberlain's great policies was the developing Turco-British relationship. For Chamberlain, the question of Turkey was entirely associated and subordinate to those of Germany and Italy, and the question of Italy, ancillary to that of Germany. He did not think deeply about Turkey but accepted the judgement of the professionals as a lawyer does his brief. The Foreign Office convinced him that Turco-British relations were important; but the military authorities persuaded him to an even greater extent that the Italians would resent anything too formal or too close and insisted that the threat from Germany would not permit Britain to divert any resources to account for possible Italian hostility. For Chamberlain, no benefit to be gained from Turkey would off-set Italian hostility. He could support no initiative likely to hamper the appeasement of Italy and was convinced that an alliance with Turkey would constitute such an initiative. ${ }^{58}$

It was preciscly in his Mediterranean policy that Chamberlain clashed with Eden. The latter had never accepted the view of the military authorities that Italy was a crucial factor; nor did he accept their contention that the appeasement of Italy and alliance with Turkey were incompatible. Eden continued to direct Britain's regional policy, the implications for TurcoBritish relations were obvious. If Britain accepted the risk of conflict with Italy it would have to develop its political relations in the Mediterranean accordingly. Potential allies, as followed from British war planning for the Mediterranean, would become important. Turkey was Britain's most

${ }^{57} \mathrm{CA} \mathrm{B} \mathrm{23/86,} \mathrm{Cab.} \mathrm{63(36),} 4$ November 1938. For the differences between Eden and Chamberlain see particularly Eden, The Eden Memoirs, and A. Peters, Anthony Eden at the Foreign Office: 1931-1938, New York, 1986.

58 Ibid. 
important potential regional ally. In effect, through the acceptance of possible confrontation with Italy, Eden's policy pointed towards alignment with Turkey, and through sanctions, Montreux and Nyon, reluctantly, and with many second thoughts, this was the path Britain had followed. The Turks were zealous supporters of this movement. In most respects their analysis of the Mediterranean situation was identical with Eden's. ${ }^{59}$

Eden's Near Eastern policy, which tended towards closer relations with the Turks, was side tracked by his resignation. Thereafter, it was not that Turco-British relations became less friendly, but that they ceased moving towards the greater and more formal relationship which had seemed inevitable. In Turkey Eden had always been perceived as an ally, and most leading Turks very much preferred his policy to Chamberlain's. Aras had worked closely with Eden in Geneva and counted him a personal friend. In Ankara, there were many who saw in Eden's resignation a sign that the policy of London was to try to placate its enemies by abandoning its fricnds'; a turning from the League of Nations to Rome; worse, an indication that Britain was secking an exclusive accommodation with the Italians. ${ }^{60}$

The 1937-1938 changes, then, brought to power in London men particularly disinclined to take the initiative in the Meditcrranean. If the development of Turco-British relations seemed to have stalled after Nyon, changes in the government of Britain was one of the reasons this was so. Turkey, meanwhile, continued to pursue an alliance with Britain as a matter of fixed policy and this remained the case before, during and after the changes in leadership both in Turkey and Britain indicated above.

The German occupation of Prague on 15 March 1939 and the subsequent apparent threat to Romania marked the sudden switch in Britain from a policy of appeasement of dissatisfied powers to one of containment of aggressors. The shift in Mediterranean strategy resulted as much from a change in personnel at the Admiralty House in October 1938 as from altered international conditions during the spring of the following ycar. In their 'European Appreciation: 1939-1940' of 26 January 1939, the Chiefs of Staff Subcommittee of the Committee of Imperial Defence had judged that the best policy in a war with Italy would be to take ruthless and immediate action against this country's position in the Mediterranean. It was decided that whatever circumstances surrounded the outbreak of such a war, the best policy remained to direct a knock out blow against Italy at the outset while remaining on the defensive against Germany. The best course, it was thought, was to apply 'maximum pressure on the weakest part of our

59 Ibid.

${ }^{60}$ F.o. 371/954/28, Loraine (Ankara) to Eden, 17 February 1938. And ibid., 1011/65, Eden to Halifax, 23 February 1938. 
enemies front, and that, in so far as we can judge in peace, that part seems likely to be Italy'. ${ }^{61}$

Moreover, in a massive report signed by the three British Chiefs of Staff on 20 February 1939, a rapprochement with Turkey was made a vital recommendation. They attached the highest importance to the military advantages to be derived from having Turkey as a British ally, in a war against Germany and Italy. This advice was central to Anglo-French strategy. The defence of the Mediterranean had been divided equally between the British and French navies; the former being responsible for the eastern half, the latter for the western end. A German penetration of the Balkan countries would have been a deadly threat to the British naval presence in the Adriatic, Acgean and eastern Mediterranean. An alliance with Ankara could interrupt completely Italian trade with the Black Sea by closing the Straits. The harbour at Izmir would be useful for operations against the Dodecanese. 'For these reasons it is difficult to overemphasise the influence which Turkish intervention on our side would have on the position in the eastern Mediterranean and the Acgean', the British Chicfs of Staff had written. ${ }^{62}$

Here was a priceless ally whose association with Britain was urgently requested as the cornerstone of Mediterranean policy. The Foreign Office recognised this and described Turkey as a 'Small Great Power'. Its policies would benevolently influence those of the other Balkan countries and, as a Moslem country, bolster Britain's influence in its numerous Moslem colonics. 63

The French readily agreed with the British on the value of Turkey as an ally in a war against Italy. Such an alliance would strengthen the French position in Syria and would facilitate the capture of Italian possessions in the Dodecanese and so eliminate that threat to the allied naval position in the Aegean. Turkish harbours and air bases could be used by the allied forces to powerfully reinforce their dominance of the eastern Mediterranean. Morcover, Turkey could provide a supply route to the Soviet Union and the Balkans and it could stop Italian trade in the Black Sea. ${ }^{64}$

61 CAB 53/44, COS 831 (JP), 'European Appreciation: 1939-1940', 26 January 1939.

62Ibid. 16/183A, D.P. (P) 44, Memorandum by Chiefs of Staff: 'European Appreciation: $1939-1940$, 20 February 1939.

${ }^{63}$ F.O. 371/23063, C5257/3356/18. Minutes by Sargent, Oliphant and Cadogan, 27 and 28 March 1939. Ibld., 23753. R2311/64, Minutes by Nichols, 28 March 1939.

${ }^{64}$ French Ministry of Forelgn Affairs Archlves. Paris (henceforth referred to as "M.A.E."), T 1930-1940, Massigli (Ankara) to M.A.E., 20 March 1939, Vol. 628, pp. 17-18. 
Alone among the armics of the Balkan countries, the Turkish army had the unquestioning respect of the Military Staffs of the European great powers. The Turkish armed forces had been in a state of semi-mobilisation for some time. Since the Bulgarians had been granted increased armaments in an agreement with the powers of the Balkan Entente signed at Salonika in August 1938 as part of a move to defuse Bulgarian revisionism, the Turkish army had felt discretion to be the better part of valour. In December 1938 the Turkish high command had strengthened the garrisons of the frontier fortifications in Thrace by the creation of a new army corps. Anxieties about the vulnerability of the Anatolian coast-line to amphibious attack from the Italian bases in the Dodecanese, had caused a similar strengthening of those forces based in Izmir. ${ }^{65}$

The British govemment's approach to Ankara subsequent to the German annexation of Bohemia and Moravia had clicited the reply that it was for Britain and France to make clear first what action they intended to take before requesting assistance. The Turkish government, in addition, was reluctant to promise adherence to any eastern combination not including the Sovict Union for the simple reason that it could not conceive how it could work. It indicated, however, that Britain itself could count on Turkish support in all cases except where Britain was attacked in the West but not in the Mediterranean. ${ }^{66}$ This meant, in effect, that Britain could rely on Turkey's help in a war with Italy. Turkey's attitude towards the German problem, however, remained contingent upon the Russian position. Failing strong British guarantees, the most that Turkey would promise against Germany was consultation. 67

On 21 March, Aras, the Turkish ambassador in London sought out, Lord Halifax, the British Foreign Secretary to state officially and uncquivocally that his country was prepared to go to all lengths with Britain in the Mediterranean and that this decision was a fixed policy decided on before he left Turkey. Aras said that the situation was that the Turkish government was quite satisfied with all its existing treaty arrangements, and quite determined to fulfil all its obligations under them. He went on: 'But before accepting any further commitments and before departing from neutrality, the Turkish government wish to be reassured on two points. The first was, generally, would they have Britain with them? And the second was, more particularly, would they have benefit of direct British assistance? At

$65_{F}$. Weber, The Evasive Neutral: Germany, Britain and the Quest for a Turkish Alliance in the Second World War, Missouri, St. Louis, 1979, p. 21.

${ }^{66}$ D.D.F., Ser. 2, Vol. 15, No. 429, Massigli (Ankara) to Bonnet, 17 April 1939.

67 Ibid., No.s 66 and 85, Massigli (Ankara) to Bonnet, 19 and 20 March 1939. 
present, in certain eventualities they would only depart from neutrality if they were on the same side as Britain. ${ }^{68}$

In Ankara, on $26 \mathrm{March}$, Saraçoğlu gave Knatchbull-Hugessen a fairly clear message. Given a satisfactory political agreement, sufficient aid, and staff talks, Turkey would partner Britain in the eastern Mediterranean at least against Italy. Against Germany, some accommodation with the Soviet Union, was a near prerequisite, and the Turkish attitude less than straightforward in the absence of one. ${ }^{69}$

By the end of March, Germany had annexed Memel and the European powers felt they were facing a project of limitless German expansion. Also in March, Franco had dealt a decisive blow to Republican Spain by entering Madrid in triumph. Nationalist Spain, indulging in an expansionist propaganda campaign, was demanding Gibraltar and French North African territories, foreboding ill for Britain and France.

As no encouragement seemed to be coming from either London or Paris where it had been decided on 21-22 March to give priority to an arrangement with Poland and Romania, leaving the larger question of Turkey, Greece and the Balkan Entente to a later time, Aras on the last day of March presented himself once more at the Foreign Office, this time to develop two ideas he stated as his own and which he gave to Halifax unofficially, although it is not difficult to guess with what official trepidation Ankara awaited their reception. Aras suggested a treaty of non-aggression among Poland, Romania, Russia and Turkey with all parties agrecing to combine against any party contravening it, the whole arrangement to be backed by a British guarantec. Regarding the Mediterranean, he asked whether other countries, Turkey, Yugoslavia and Greece, could accede to the Anglo-Italian arrangement of 16 April 1938 for the preservation of the status quo, and implied that they would be ready to do so; and if Franco-Italian relations improved, France, too might eventually join. 70

It was a far-reaching proposal designed to stabilise relations amongst the powers most interested in resisting German aggression, obviously the first step towards an effective containment front. It would have involved the Soviet Union and Britain in the Balkans with Turkey as the linchpin in a

${ }^{68}$ B.D.F.P., Ser. 3, Vol. 4, No. 472, Halifax to Knatchbull-Hugessen (Ankara), 21 March 1939.

${ }^{69}$ F.O. 371/424/283, C4141/3356/18, Knatchbull-Hugessen (Ankara) to Halifax, 26 March 1939.

${ }^{70}$ B.D.F.P., Ser. 3, Vol. 4, No.s 458 and 484, Record of conversations during the course of Georges Bonnet's and Edouard Daladier's visit to London, 21-22 March 1939. Ibld., No. 590, Halifax to KnatchbullHugessen (Ankara), 31 March 1939. 
pact couched in terms as inoffensive to Germany as possible, with the added benefit of conccivably involving Italy in peace-kecping operations. By normalising relations between the Soviet Union on one side and Poland and Romania on the other the proposal would have neutralised Germany's ace of trumps. It might have involved the Balkan Entente with Britain in a form acceptable to Italy. A proposal of this nature would probably have been considered an intolerable affront by both Germany and Italy at any time after April 1939, but placed in the anxious context of the Prague aftermath the proposal had real merit and real possibilities. 71

Halifax failed to understand both its importance and the logic behind it. He asked how an undertaking by those countries not to attack each other would really strengthen the common front against German aggression. Aras gave him the obvious answer: it would dispel their mutual suspicions. After all, since this was the central difficulty in the way of Polish-RomanianSoviet co-operation, it would prevent the possibility of a Nazi-Soviet agreement to crush Poland and Romania and then turn on the rest of Europe. These explanations did not make Halifax more enthusiastic. Aras went further. He drew attention to the fact that under the special protocol of 1929 attached to the Turco-Soviet Treaty of Neutrality and Non-aggression neither party was at liberty to make an arrangement with a neighbour of the other party without the latter's consent. Consequently, if there was any idea of forming a block with Turkey or Romania (or Poland) this could only be done with Soviet consent and it was, therefore, imperative that Soviet-Romanian relations and Sovict-Polish relations be put on the best possible footing immediatcly so that Russia might not wish to bar any treaty relations between Turkey and those two countries. This was, of course, preciscly the position Turkey found itself in when, after Britain and France extended a guarantee to Poland and Romania, they sought to make it operative by enlisting Russian help. ${ }^{72}$

It may be argued that Aras' proposals were overtaken by events. More likely they were dismissed. The Foreign Office surrendered to events especially where Polish-Romanian relations with the Sovict Union were concerned. At the end of March a proposal for a reciprocal guarantee to Poland and a non-reciprocal guarantee to Romania (dependent on those two countries making their treaty arrangements operative against German aggression) had been laid before those governments while no step was taken to involve the Soviet Union or Turkey. The weakness of the proposal was exposed within days when the Polish and Romanian governments acquainted London with their unwillingness to co-operate against Germany. And when, a few days later, Italy's aggression against Albania seemed to pose a threat to

71 Ibid.

72 Ibid. 
Greece the roles were reversed and Britain found itself placing before Turkey the same consideration that Aras had put to Halifax. ${ }^{73}$

On 7 April, not entirely happy with the policy of the British govemment, yet unable to construct a better, Grigore Gafencu, the Romanian Foreign Minister and currently President of the Permanent Council of the Balkan Entente and Saraçoğlu, meeting in Istanbul, decided to follow a common line with the Western powers aimed at containing German aggression. ${ }^{74}$ On the same day, as Saraçoğlu and Gafencu deliberated in Istanbul, Italy invaded Albania. Mussolini's occupation of Albania caused great concern in London regarding the possible continuation of Italian expansion in the direction of the Balkans and the Near East. The Whitehall considered that the moves of Italy and Germany had been closely orchestrated and that the Axis had far-rcaching aims. For the first time since Nyon, Italy appeared unequivocally among Britain's possible enemics. In Turkey, the invasion marked the return of Italy to first place in Turkey's demonology. In Turkey, as in Italy and France, it was axiomatic that an Italian invasion of Albania would be only the spearhead of a general Balkan advance. ${ }^{75}$

Turkey's leaders reacted to the Italian invasion of Albania by calling three classes back to the colours, approving a new credit of 215 million Turkish liras and recalling various specialist troops to give them in all 250,000 men under arms; of these, the bulk, 100,000 or so, were in Thrace, 50,000 or so were in western Anatolia and the remainder scattered through the country. German military reports put eight infantry and one cavalry division in Thrace with steady reinforcement through the spring and summer. Whoever else was to be caught out, it was not to be the Turkish high command, which eyed the steady building up of Italian forces in Albania (some twenty Italian divisions were widely reported there) with the deepest suspicion. ${ }^{76}$

It is worth recording that developments culminating in the Italian action in Albania had caused all Turkish newspapers to publish leading

73 Ibid.

${ }^{74} \mathrm{G}$. Gafencu, Derniers Jours de l'Europe: Un Voyage Diplomatique en 1939. Paris, 1947, p. 67 and B.D.F.P., Ser. 3, Vol. 5, No. 278, Minutes of the Conversation of Halifax with Gafencu, 24 April 1939.

75 P. B. Kinross, Atatürk: The Reblrth of a Nation, London, 1964, p. 545; D. M. Smith, Mussolinl's Roman Empire, New York, 1977, pp. 150-154; H. M. Knox, Mussolini Unleashed, Cambridge, 1982, pp. 4041; A. Adamthwaite, France and the Coming of the Second World War, London, 1977, p. 309.

${ }^{76}$ H. Kroll, Lebenserrinerungen eines Botschafters, Cologne, 1967. p. 108. Kroll was the Counsellor at the German Embassy in Ankara on the eve and most of the years of the Second World War. 
articles which reflected one common patriotic thought, and, in energetic, but measured terms, expressed a stubborn determination to preserve Atatürk's legacy. The following extracts would give an idea of Turkish public opinion: 'Of course, Turkey is neither a Czechoslovakia, nor an Ethiopia, nor an Albania. Everybody knows it. Recent history has shown how, deprived of everything, betrayed by its government, sold by its Sovereign, without arms or ammunition, the Turkish nation has been able to throw its adversary into the sea. The men who led our people through these great trials are still with us. Certainly we have lost an incomparable genius, but we still have his closest licutenants, his companions in arms who watch over his legacy. ${ }^{77}$ In the Tan, Zekeriya Sertel recommended the forming of a Balkan confederation, and after describing the situation of Romania and Yugoslavia with regard to Germany and Italy, the Italian threat over Grece, as well as the GermanoItalian propaganda in Bulgaria, stressed the implicd threat against all Balkan countries. ${ }^{78}$ 'When speaking of Turkey, our Italian friends should change their tone. We, Turks, are for peace in the country, peace in the world. We are neutral not because we lend our ears to Italian threats or because we are reduced to rely on anyone's assurance or guarantee. We rely only on one guarantee, the guarantee which is given us by the Turkish army. ${ }^{79}$

In Ankara, Refik Saydam, the new Prime Minister, made a statement of foreign policy in the Grand National Assembly on 11 April. Saydam said that Turkey was watching the development of the international situation with great attention and concern. Though it had only friendly feelings towards all countries, great and small, and intended to remain faithful to its commitments, Turkey would not fail to safeguard itself to its utmost capacity against any danger, direct or indirect. Thanks to its mighty armed forces, Turkey was fully prepared to repulse any attack. He continued: 'In these times, when ideas and interests conflict with such violence, no ideology or passion of interests will make Turkey deviate from the path of peace. No act capable of imperilling the life or well-being of the Turkish nation will come first from your government, unless our good will, our sincere and friendly neutrality towards all states, should be directly or indirectly the object of an attempt at violation.' The Prime Minister emphasised that Turkey had given proof of its vigilance by taking measures against events which the Turkish nation might possibly have to face. He went on: 'Backed by its strong, intrepid army, Turkey remains vigilant in face of the present world crisis, which raises nation against nation, bringing about the disappearance of states within a few days. Faced with an international

\footnotetext{
77 Ahmet Ağaoğlu, Ikdam, 9 April 1939.

${ }^{78}$ Zekeriya Sertel, Tan, 10 April 1939.

${ }^{79}$ Asim Us, Vakit, 12 April 1939.
} 
situation of the greatest danger, the Turkish government maintains its loyal, correct attitude towards all states, both large and small. ${ }^{, 80}$

The initial reactions of Lord Halifax to the Italian attack on Albania struck Saraçoğlu as hesitant and lacking in firmness. For a moment Saraçoğlu was baffled and discouraged, and his first reactions to the news of the British guarantecs to Romania and Greece and the British proposal that Turkey should extend its alliance with Greece to cover attack from Italy were cold and on the sniffy side. Bluntly Saraçoğlu remarked to Sir Hugh that his government was not prepared to put itself irretrievably on the side of Britain without some definite British guarantec of Turkey's own security. ${ }^{81}$ No doubt he was thinking of the Italian naval and air bases in the islands of the Dodecanese, a barrier across the entry to the Aegean, and only minutes' flying time away from the citics of Turkey's Aegean coast-line. ${ }^{82}$

The position, however, was immediately altered by the British decision to guarantee Romania without waiting to straighten out the PolishRomanian relationship. On 12 April the Turks were belatedly offered the treaty of mutual assistance they themselves had proposed three weeks before. ${ }^{83}$ It was now up to the Turkish government to examine the tardy British offer in the light of their own security requirements and the developments of the last few weeks. The Turkish reply was returned on 15 April. Turks were not prepared to come to the aid of Romania with their military forces, which they anticipated would be fully engaged in the defence of the Dardanclles. They insisted on Soviet co-operation. They emphasised the importance of attempting to settle Romania's difficultics with Bulgaria. But in the event of war in the Mcditerranean, and on these terms, Turkey would fight on Britain's side. ${ }^{84}$

Although highly circumscribed, it was an encouraging answer and negotiations during the next two weeks proceeded along normal diplomatic lines with both sides showing goodwill neccssary to bring them to a successful and early conclusion. On 23 April Saraçoğlu had spoken of a treaty of alliance lasting fifteen years, and within the wcek the British had suggested four steps in the negotiations the issue of a joint declaration stating the two governments' intention to arrive at a permanent treaty of

80 Anatolian News Agency, 12 April 1939.

81 B.D.F.P., Ser. 3, Vol. 5, No.s 119, 120, 121 and 124, KnatchbullHugessen (Ankara) to Halifax, 10 April 1939. Massigli (1964), p. 132.

82 Ibid., No. 128, Halifax to Knatchbull-Hugessen (Ankara), 11 April 1939. Massigli, La Turquie devant la Guerre, p. 139.

83 Ibid., No. 138, Halifax to Knatchbull-Hugessen (Ankara), 12 April 1939.

${ }^{84}$ Ibid., No. 199, enclosures 1 and 2, Saraçoğlu to Knatchbull-Hugessen, 15 April 1939. 
mutual assistance and providing for reciprocal help in the interim period; discussions to settle the political, financial and military clauses; and, finally, the conclusion of the definite treaty. ${ }^{85}$

Lord Halifax explained that he thought the Germans were feeling around to creatc apprehension wherever they could, and that when they found a weak place they would exploit it. Hence the importance he attached to a rapid and public strengthening of the ties of solidarity between all the states that felt themselves threatened. 86 This was, very broadly, the Turkish view, but the Turks drew a considerable practical distinction between Germany and Italy, based on the limits of their own effective action. What they hoped for was a triangular structure of agreements, between Britain and the Soviet Union, between themselves and the Sovict Union and between themselves and Britain. To the first of these they attached immense importance but had little practical to offer. The second they envisaged as covering the Balkans and the Black Sca only. The third fell into two parts: against Italy, automatic co-operation in the event of war in the Mediterranean; against Germany, cooperation only if war spread to the Balkans. ${ }^{87}$ This division was explained by reference to the Soviet Union. It was picked up by Lord Halifax and incorporated in the British draft of the declaration.

By 6 May, the Turkish and British governments had decided upon a draft of a mutual assistance declaration and the French were informed of its existence. The French approved of the draft and suggested that it become tripartite, but by that time it was already clear that Turkey regarded the French attitude over the Hatay question as completely unsatisfactory. The Turks refused to announce the declaration in triple form until a definite agrecment on Hatay had been reached. On 9 May, the British informed the French that they held it very essential that the French make a declaration corresponding to theirs with Turkey and they offered to postpone the announcement of their agreement while the final arrangements about Hatay were made. ${ }^{88}$

The French felt unable to concede Hatay at that moment. The British were impatient with this reply and increased the pressure on France by claiming that Franz Von Papen, the new German ambassador, might dissuade the Turks from their friendly attitude at any time. As a matter of fact, for the

85 Ibid., No. 271, Knatchbull-Hugessen (Ankara) to Halifax, 23 April 1939.

86 Ibid., No. 276, Halifax to Knatchbull-Hugessen (Ankara), 24 April 1939.

${ }^{87}$ Ibid., No.s 286, 287 and 291, Knatchbull-Hugessen (Ankara) to Halifax, 26 April 1939.

${ }^{88}$ Ibid., No. 396. Halifax to Phipps (Paris), 6 May 1939; M.A.E., Private Papers of René Massigli, PA-AP: 217, Massigli (Ankara) to M.A.E., 12 May 1939. Vol. 26, p. 391. 
Germans in particular, it was important that, in any general war that might break out in Europe, Turkey should remain neutral and the Straits closed against the fleets of the Western powers. On the eve of war in 1939, therefore, they were at pains to prevent Turkey joining one of the diplomatic combinations their principal opponents, Britain, France and Russia, were endeavouring to raise against them. As Von Papen put it, on the occasion of his appointment in April 1939, in the event of war the Turks must be persuaded to adopt 'the strictest neutrality' and 'close the Straits to everyone'. 89

In the meantime, the arrival in Ankara of the new ambassador of the Reich, Von Papen, had drawn increased attention to Turco-German relations. For several years past it had been possible for the average Turk to harmonise his sentiments with the official Turkish political credo in all circumstances strictly to follow an essentially Turkish policy and, to that end, not to concern itself with any foreign state system. Recent developments, however, had stirred public opinion and caused the press to take a stand in matters which, it was now felt, might happen to be of direct Turkish interest. With the exception of a very small, but largely circulated, section of the Turkish press, unquestioned preference was now given to the Western democracies, despite a traditional and deeply-rooted consideration for German ability and efficiency, and it should be added, despite what appeared to be a wellorganised and well-planned pro-German propaganda. That propaganda was partly based on Turco-German economic bonds, and particularly on the opportunitics of easy profit offered to merchants and intermediaries doing business with Germany. It did not, however, escape the attention of a great number of people that Turkish dependence on German economics, although of immediate advantage, might in the long run prove unfavourable to Turkey's real interests, and surprise was frequently expressed at British delay in enabling Turkey to export its goods to other countries than Germany. Such assistance, it was said, should be independent of loans, and rather aim, through some subsidised organs, at making it possible for the Turkish importer or exporter to do business with Britain without affecting the existing Turkish price level. ${ }^{90}$

On the other hand, the Turco-British negotiations were moving to their conclusion. The British dramatically postponed the announcement of their agreement with Turkey an hour at a time to further increase the pressure on France in hopes that it would join them. Nonetheless, the French refused to come to terms and on 12 May, while the negotiations were in the midst of

${ }^{89}$ D.G.F.P., D.V., no. 288, 23 April 1939.

90 Ulus, Special Issue, 1 April 1939. This special number was devoted to Britain, in which Turco-British friendship was emphasised. The purpose of the special number was largely to thank Britain for the interest it had taken in Turkish affairs. 
their difficulties, Britain and Turkey signed a declaration of mutual cooperation and assistance whose articles could be briefly outlined as follows:

1. Subsequent conclusion of a long-term reciprocal defence treaty;

2. Mutual guarantees. Pending the completion of the definitive treaty, Turkish and British govemments declare that in the event of an act of aggression leading to war in the Mediterranean area, they would be prepared to co-operate effectively and to lend each other all aid and assistance in their power,

3. The guarantee would not be directed against any country and was defensive in nature;

4. Additional and more definite talks were to procecd;

5. Turkey and Britain would consult on how to ensure the stability of the Balkans;

6. The freedom of either signatory to enter other agrrements. 91

The French regretted that the Hatay question should have prevented the Turco-British agreement from becoming a tripartite accord with their participation.The French had given their cogratulations wholeheartedly, though they were naturally disappointed that some last-minute points of detail obstructed their announcing a similar declaration with Turkey at the same hour. ${ }^{92}$

For Lord Halifax and his advisers, the declaration itself, even the alliance, was important mainly for the anchor it would provide for the security line they were attempting to call into existence in southeastern Europe. The role of the Turks was to bolster and buttress Romania, and through Romania, Poland. Turkey was to persuade its partners in the Balkan Entente to damp down the conflict with Bulgaria, so far as was possible, within the bloc. The extent of the declaration as laid down was the widest commitment Britain had yet made in its effort to build up a European alliance against Axis agrression. If the Axis powers started anything in either the Mediterranean or the Black Sea, Turkey and Britain were in it together. If Turkish interests were affected by any action taken by the Axis powers in the Balkans, Britain was in it. And if Britain became involved anywhere in the Mediterranean area or the Balkans -either because of its Mediterranean interests or because of its new guarantees to Greece and Romania- Turkey would come to its aid with every military force it possessed. In other words, it was a complete agreement on Turco-British cooperation against Axis aggression anywhere east of Italy. 93

91 F.O. 371/424/283, T6131/436/384, Halifax circular, 11 May 1939.

92 Massigli, La Turquie devant la Guerre, pp. 159-161.

93 Ibid. 
In the Grand National Assembly, before reading the articles of the declaration, Premier Saydam spoke as follows:

You know political events have occurred lately with lightning speed and have seriously occupied the attention of those burdened with the responsibilities of government. At first this government decided Turkey's best course was to remain neutral but when events involved the Balkan peninsula and raised the question of security in the eastern Mediterranean, we were forced with a situation pregnant with danger which made it impossible fo us to remain neutral. It is our conviction that the Mediterranean should be free to all nations on a footing of equality, and any attempt to interfere with that freedom would endanger Turkish security. Believing this danger now exists, we have made up our minds to co-operate and, if necessary, to fight with those equally anxious to preserve peace. ${ }^{94}$

After reading the declaration, Saydam went to great lenghts to explain the reasons for his country's abandonment of neutrality. It was a vital Turkish interest, he stated, that all the countries in the Mediterranean should have free exercise of their rights without any encouragement being given to the idea of hegemony. Now that trouble had extended to the Mediterranean and Balkans, to remain neutral would jeopardise Turkey's security. The best way to avoid war was for Turkey to associate with those countries which were invited together for peace but not shrinking from war if necessary. The Prime Minister stressed that the declaration was aimed at no one country but also that Turkey and Britain would oppose by force any threat to their rights and interests. For that reason he was asking the Grand National assembly to approve association of Turkey and Britain in defence of peace and security an association nourishing no aims of encirclement but designed rather to ward off catastrophe of war. Saydam expressed conviction that declaration, together with subsequent agreements foreshadowed in it, would help notably to weigh down the scales on the side of peace. Policy of Turkey and its ally was to keep peace and to attack the rights of no one. In pursuit of peace Turkish government would continue to exert every effort. He added that negotiations were going on with France and that his country was keeping in close touch with the Soviet Union, with which country there was a complete identity of views. Lastly, as an amplification of Articles 5 and 6 of the declaration, he registered the hope that the Balkan Entente might be further enlarged and fulfil a still more useful function. 95

Fethi Okyar, Minister of Justice and the former ambassador in London, supporting a motion in favour of the declaration, said Turkey entertained good relations with all nations and had been developing its

94 Anatolian News Agency, 13 May 1939.

95 Ibid. 
national resources, when a cataclysm had shaken the foundations of peace and security. Czechoslovakia had been wiped of the map in 24 hours, he recalled; Romania had been the object of a veiled ultimatum and Albania had lost its independence at the hands of 'a great power' which already possessed islands close to Turkish shores and had concentrated there troops and war materials. Treaties and solemn pledges had been violated, he continued, and as a consequence an atmosphere of fear and insecurity had been created. The Turks want peace and threatened no one, he added, but others were threatening. Turkey's forces, combined with those of Britain, he went on, would, however, be able to repulse any danger, and in a hour of need the Turkish nation, inspired by the spirit of the late President Atatür, would again display the same heroism as in the past. ${ }^{96}$

The Turkish press of 14 May commented very favourably on the Turco-British Declaration and printed extracts from articles published about it in British, French, German and Italian newspapers. Cumhuriyet said that Turkey was not an artificial country created by diplomats at a round-table conference; its great history did not allow it to accept the theory that nations must be defeated and the masters ensiaved. Akşam wrote that Turkey's position was clear. It could not accept the 'living room' argument with which some great powers cloaked their expansionist ambitions; still less could it admit that the Balkans be used to satisfy such ambitions. Tan hoped that this declaration, the sole object of which was the preservation of peace, freedom and security in the Mediterranean, will be followed by others conceived in the same spirit. Son Posta said that if a country like Turkey, which had steadfastly worked for peace, found it advisable to join forces with the democracies, it meant that it was convinced that peace was seriously endangered and that the assistance of all was necessary to join forces with the democracies to save it. Yeni Sabah stated that none could reasonably accuse Turkey of aggressive intentions towards Germany and Italy. The stand which it had taken could, thereforc, be attributed only to the fear of aggression from those countries. If this fear was groundless so much the better and the totalitarian states, instead of taking umbrage, could by their actions very easily dispel it. The semi-official Ulus, under the headline, 'Historic Decision', wrote that the Turkish and British nations had undertaken new duties and responsibilities for a noble ideal, the maintenance of peace; the friendship and esteem which they had for one another would help towards its achievement.

On 30 June, the Grand National Assembly ratified the declaration. On this occasion, Saraçoğlu spoke. The declaration, he told the Assembly, was

${ }^{96}$ Ibld. 
the last step in Turkey's reconstruction and the last logical step in a chain of events beginning with Ethiopia and including Montreux and Nyon.97

In the House of Commons, Premier Chamberlain announced that the declaration was not directed against any country but was designed to assure Turkey and Britain of mutual aid and assistance if the necessity should unhappily arise. Each country was in need of the other and each brought important political and strategical contributions to the common defensive fund. Chamberlain stated that the Anglo-Turkish arrangement did not preclude cither government 'from making agreements with other countries in the general interest of the consolidation of peace'. The form of French association was to remain for decision by Turkey and France. ${ }^{98}$

The British government was widely praised for the declaration. 'Unreservedly and unequivocally', David Lloyd George said, 'I congratulate them upon the Turkish agreement. It is of great vaule'. But the guarantec, he warned, would not be sufficient to ensure safety from the dictators unles accompanied by increased armaments and a Soviet alliance. The real solution was not Turkey instead of Russia, he said, but Turkey and Russia. 99

Winston Churchill, too, applauded the declaration. The news of the Turkish guarantee, he said, were 'rare and fresh fruit, the more refreshing because perhaps, unhappily, they are somewhat rare'. He, like Lloyd George, hoped that the alliance might be a signpost on the road to agreement with Russia, because, he reminded the House, in the Balkans, Britain and Russia had a virtual identity of interest. 100

Archibald Sinclair, for the Labour Party, warned that the declaration would not likely be operative without a corresponding Sovict agrecment. 'Do not let anyone suppose', he warned, 'that if any one of the countries in the Mediterranean area which we have guaranteed were the object of aggression next week, that Turkey would necessarily move a man, a ship, or a gun. Turkey would not move unless and until [...] the cooperation of Russia were assured'. 101

Lloyd George and Churchill were correct. The fact that the guarantecs had gone forward without any reference to the Soviet Union was an extravagant slight which Moscow did not soon forget and, in Turkish eyes, constituted a flaw which in isolation might have proved sufficient to deprive

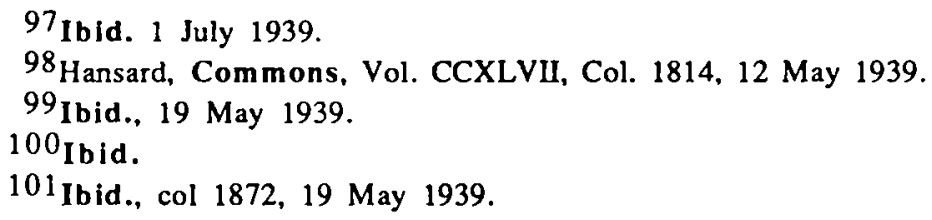


the guarantee of most of its value. The fears of Whitehall's critics were shared by the military authorities who tended, like Lloyd George and Churchill, to see a Soviet connection as the logical next step following from an alliance with Turkey. 102

The declaration and the prospect of a long-term treaty had been greeted, rightly, with the utmost enthusiasm by the Turkish and British nations. But it had no appearance of a panic measure. Long ago the seeds of Turco-British friendship were sown. One should not speak of the historic connections between the Sublime Porte and London, for they were severed -it might have been thought irrevocably severed- by the Great War and its unfortunate aftermath, when the Greeks were sent to invade Anatolia. Rather, one should think of the patient and convicing efforts of successive British ambassadors in Turkey, of Sir Ronald Lindsay, of Sir George Clark, of Sir Percy Loraine, and of Sir Hugh Knatchbull-Hugessen, during whose terms of office this consummation had been reached. Through the untiring effort of these men, whose activities were mached by those of far-seeing men of the Turkish side, among whom, without invidiousness, might be mentioned Atatürk, Inönü, Aras and Okyar. Such men as these it was who saw the true interests of their respective peoples, and they might rightly be regarded as the chicf architects of this imposing pillar of peace.

Yet, despite the visible growth of Turco-British understanding and friendship, Turkey undoubtedly would have preferred to remain neutral, had neutrality been possible. Pcace was dictated by its internal necessities, and nothing could more gravely impair its programme of reform than renewed preoccupation in war. But the force of circumstances had rendered neutrality impossible. The average Turk thought that the danger to his country was greater from Italy than from Germany, for he had never accepted at their face value the protestations of friendship from Rome. But he fully realised that in the Mediterranean Italy would never move alone, and that the weight of the great power on the north of the Balkan Peninsula might in emergency attempt to make itself felt against the shores of Asia.

The declaration was received in the West with predictable jubilation. Out of the improvisations of March and April, when Poland, Romania and Greece had been extended hasty guarantees, an embryonic containment front was now beginning to take shape which, it was hoped, would eventually link Britain and France with the Balkan Entente and Russia. Its linchpin was Turkey. 103

${ }^{102}$ See I. Maisky, Memoris of Soviet Ambassador, London, 1967, passim.

${ }^{103}$ F. Marzari, 'Westem-Soviet Rivalry in Turkey: 1939-I', Middle Eastern Studies, Vol. 7, No. 1, 1971, p. 72. 
General Italian opinion was especially perturbed by the adhesion of Turkey to the anti-aggression front. Italians were quick to perceive that the Turco-British declaration radically altered the whole strategic position in the eastern Mediterranean. In Rome, Mussolini questioned the British ambassador Sir Percy Loraine: did Britain still consider the Anglo-Italian arrangement of 16 April 1938 for the preservation of the status quo in the Mediterranean as valid? If so, how could it reconcile this arrangement with the latest policy of encirclement which Britain seemed to be following. 104

By the patent desire in Turkey to link up with the anti-aggression front, Germany was profoundly disappointed. For years it had had, in the material field, a privileged position in Turkey, and there was no question that it had been banking on a policy of neutrality in Ankara. The Berlin press, which had hoped that, by dint of material circumstances, Turkey would be such an economic vassal of Germany as at least to ensure neutrality in the event of war, was chagrined, lamenting that the Ankara government had placed its people under the vassalage of Britain. 105

The first German comment on the Turco-British declaration in the National Zeitung of 13 May stroke a menacing note:

After years of a happy and healthy foreign policy, Turkey has abandoned the path of neutrality and, by the conclusion of a pact of mutual guarantee with Britain, has joined the British aggressive pact system directed against Germany and Italy. The Turkish government is playing the British game. They will not be in any doubt as to the consequences which Turkish participation in the policy of encirclement will naturally have for Turkey. Only recently Turkey gave the Reich binding assurances on the observance of a policy of strict neutrality. With the Anglo-Turkish Pact, however, the Ankara government has left this path and made themselves vassals of a policy, the only aim of which could be collective war on behalf of Britain. In view of the Berlin-Rome Axis and the gographical position of Turkey, it will be possible for Ankara itself to form an opinion as to whom this conclusion will affect the most. It should not, however, be imagined there that the limitation of this pact to the Mediterranean will leave a less negative impression in Berlin than -as is also contemplated- full participation of Turkey in the British encirclement system. Britain and Turkey should note that Germany and Italy remain inseparable fihting companions in every case of the present and future, and against every combination.

The Deutsche Diplomatische-Politische Korrespondenz of 14 May accused Turkey of departing from the Montreux Convention, which, it was

104F.O. 371/1011/77, Loraine (Rome) to King George VI, 27 June 1939. ${ }^{105}$ Marzari, Western-Soviet Rivalry in Turkey, pp. 72-73. 
asserted, presupposed that its guardianship of the Dardanelles would be exercised in the interests of all states. Now, the writer added, Turkey was no longer a neutral state, but was bound to Britain in an open alliance, which envisaged the support of either partner for the other should one of them became involved in a Mediterranean conflict. 'So Britain', he continued, 'has obtained by roundabout ways its old objective, which evaded its efforts even during the Great War [...] the possibility of using all Turkish harbours and refuges, but above all the Dardanelles as a base of operations, in any conflict affecting Britain - which in all circumstances must affect also the Mediterranean in some way or other'. The writer proceeded to complain that the alliance was directed against Germany on the ground that the Reich would automatically be involved in a Mediterranean war in which Italy was a participant. For the time being, he conceded, Turkey seemed to be careful about taking over the Balkan obligations desired by Britain. Obviously, this indicated a certain reluctance to come into a conflict with the German Reich, which according to British propaganda, was the potential aggressor there. At the same time, it seemed to have been forgotten that immediately on the outbreak of a conflict in the Mediterranean, in which Italy stood on one side, every one must know that Germany would also be on that side.

Soon after the announcement of the Turco-British declaration, Von Papen, the German ambassador in Ankara, was recalled to Berlin to report to the Reich government. It was stated that his visit to Germany, which would be short, was envisaged when the ambassador went to Ankara a month ago. In the hope, presumably, that he would be able to exert some influence in the Turco-British and Turco-French negotiations, Von Papen was sent off at such short notice that he had no time to pack trunks, and he was now returning to make the necessary arrangements for a prolonged absence from Germany. The fact, however, that the Reich government had scen fit to announce that he was recalled to report suggested an expression of the annoyance undoubtedly felt with Turkey in offcial circles in Berlin. ${ }^{106}$

Since the Turco-British declaration was signed, indeed, the strategic aspect of the Mediterranean was profoundly altered. And if the Russian adhesion to the anti-agrression front could be secured, the potentialities of the southeastem European and of the eastern Mediterrancan position would assume a new significance. The motives of the historic 1915 attempt to force the Dardanelles had to be seen, and realised, in their full perspective, and that at the outset of any conflict. The conclusion of the Turco-British agrecment therefore led to a threatening posture on the part of the German government. The British were accused of luring the Turks into their policy of 'encirclement', and the Turks were wamed to revoke this agreement and not to

106 Papen, Memolrs, pp. 446-447. 
conclude any more like it. ${ }^{107}$ The Axis retort to the Turco-British Declaration of 12 May was the Pact of Steel of 22 May. 108

The mutual assistance agreement arranged by Turkey and Britain was warmly welcomed in Moscow as an important link in the chain being forged to hold further encroachments by aggressive powers. The government newspaper Izvestia devoted its leading editorial on 15 May to a favourable comment, emphasising Turkey's strategical position and the close bonds of friendship between Turkey and the Soviet Union. The Turco-British declaration was greeted by Izvestia as 'one of the links in that chain which was the only sure means of preventing the extension of aggression to new parts of Europe. The people of the Soviet Union and all sincere partisans of peace in all countries will value the conclusion by Turkey of the agrecment with Britain for mutual assistance as an investment in the cause of strengthening universal peace, which has always been most consistently defended by the Sovict Union.' Izvestia emphasised Turkey's wisdom in taking steps to defend itself against 'the predatory lusts of aggressive countries' and Russia's close friendship with Turkey. This friendship, said the newspaper, quoting the statement made by Saraçoğlu last autumn, did not represent an empty political fiction, but was a fact having origins in the most important events dating from when the new regimes were set up in Turkey and the Sovict Union. Russian interest in the Balkan security was stated plainly. Threats to Balkan independence from 'certain imperialist states conceal also a threat to other countries which are vitally interested in the free use of the sca communications along the shores of the Balkan Peninsula, in the Mediterranean and connecting the latter via the Straits with the Black Sea.'

The Balkan reception of the Turco-British declaration was, on the whole, unfavourable. The Romanians observed that, while they agreed with the idea, they considered so formal and bindig a declaration to be provocative. Yugoslavia's disagreement was more violent. On 10 May, Prince Paul, the Yugoslav Regent, arrived in Rome and over the next week, amidst the pomp and panoply of the five-day state visit, explored with Ciano the possibilities of forming a Balkan bloc excluding Turkey, aligned with the Axis. The Italian argument were that Turkey, in signing the declaration with Britain, was acting on its own in a matter concerning the whole of Balkans. The Italians considered that Turkey had disturbed the current Mediterrancan status and disregarded the interests of Yugoslavia. Turkey's sin could be atoned only

\footnotetext{
${ }^{107}$ M.A.E., T 1930-1940, Coulondre (Berlin) to M.A.E., 10 June 1939, Vol. 628, pp. $151-152$.

108 See M. Toscano, The Origins of the Pact of Steel, Baltimore, 1967, pp. 250-340.
} 
by Yugoslavia's agreeing to leave the Balkan Entente or, failing that, by the creation of a new Entente which would include Italy. ${ }^{109}$

On the other hand, in Belgrade, reports that Yugoslavia had made a protest in connection with the Turco-British declaration were authoritatively denied. Diplomatic inquiries only were being made in a friendly manner as to the extent of the agreement and its possible repercussions on the Balkan Entente and on the existing mutual obligations of members of the Entente. The newspaper Politika, in an inspired article on 14 May, stated that Turkey had changed suddenly its attitude, which had been the stance of its Balkan allies, and that it adhered now to a bloc of powers under the influence of event, which in Turkish opinion had endangered security in the Mediterranean. The Turkish Premier (said the journal) declared that the position of Turkey within the Balkan Entente remained unchanged. But it was certain that the centre of gravity of Turkish interests was being transferred all the same to the Mediterranean. The writer in the end asked: was it because these Metirerranean interests were so great or so endangered that in future all Turkish actions should be determined by those interests alone?

That Yugoslavia, of all countries, should now complain of Turkey's action towards Britain came oddly from a government which in the last few years had been 'swinging loose', consulting at all times (as any government ought to do) what it considered its own best interests. The Balkan Entente was no more harmed by the Turco-British declaration than it was by Yugoslav-Bulgarian pact and Yugoslav-Italian understanding. The integrity of the Balkans was in fact one of the main aims of Turkish diplomacy, and it was hard to understand that in the resolute pursuit of this Turkey should have to suffer criticsm by its friends.

Meanwhile, on 15 May, the French Foreign Minister Georges Bonnet instructed Massigli to begin negotiations aimed at returning Hatay to Turkey. On 23 June, when an agreement for the reunification of Hatay with Turkey was signed, a declaration, identical in its terms with the Turco-British declaration, was issued in Ankara and Paris. ${ }^{110}$

It should particularly be noted here that the sympathetic support of Turkey by Britain in the question of Hatay undoubtedly contributed to the growing Turco-French cordiality. Throughout the crisis over the district of Hatay between the years of 1936 and 1939, France was continually urged by the British to reach an agreement acceptable to Turkey.

109 G. Ciano, Clano Dlary: 1939-1943, London, 1947, pp. 85-89, entries for 10 and 18 May 1939.

${ }^{110} \mathrm{G}$. Bonnet, De Munich à la Guerre, Paris, 1967, pp. 270-271. 
The Turco-British and Turco-French declarations represented for all three parties the starting point for negotiations intended to culminate ultimately in a formal tripartite pact of mutual assistance. The intervening period was to be covered by an interim agreement, discussion for which began (and procceded pari passu with talks about the tripartite pact) immediately the declaration was announced in Ankara, London and Paris. But, whereas the declaration had been agreed upon in a surprisingly short time, the ensuing negotiations were allowed to drag on for more that five months, during which the political circumstances altered appreciably. The Western powers contributed to the delay by insisting on a precise Turkish commitment to the guaranteed countries, Greece and Romania, while Turkey, on its part, continued to postpone action until it had received substantial Western military and financial aid. During this period, the political factors which had originally led Turkey to seek an alliance with the West -Italy's bellicosity and Russia's friendship-changed so radically that the beginning of hostilities found Italy neutral and the Soviet Union Germany's collaborator. ${ }^{111}$

These developments were not foreseen in May when the two sides first defined their aims in preparation for the interim agrcement. Turkey's attitude was that according to the stipulations of the Balkan Entente, it was under an obligation to help Grecce if that country were attacked by Bulgaria or by a third power (Italy excluded at Grecce's request) acting in concert with Bulgaria; and also to help if Greece were involved in hostilities in the eastern Mediterranean which brought into play the British guarantee and the TurcoBritish declaration. Its attitude towards Romania was a great deal more cautious. Saraçoğlu could foresee three eventualities: first, an Italo-German attack extending to the Balkans; secondly, the unlikely but possible neutrality of one Axis partner while the other attacked in the Balkans; and lastly, agreession against Romania by a power other than Italy or Germany. In the last instance, unless the aggressor was Bulgaria, in which case the provisions of the Balkan Entente came into effect, Turkey was not disposed to help Romania, particularly not against Russian attack. In the first two eventualities, Saraçoğlu stated that there existed no legal obligation to help Romania and that Turkey did not wish to assume such a responsibility unless its security was directly threatened. 112

London found this attitude little short of disingenuous. In British eyes, the point of helping Turkey in the eastern Mediterranean was to secure Turkish help in implementing the guarantee to Romania. The point had been expressed during April. Late in that month the difficulty of finding an

111 F. Marzari, 'Western-Soviet Rivalry in Turkey: 1939-II', Middle Eastern Studies, Vol. 7, No. 2, p. 201.

112 B.D.F.P., Ser. 3, Vol. 5, No. 641, Knatchbull-Hugessen (Ankara) to Halifax, 26 May 1939. 
acceptable formula to cover Romania combined with the simultaneous presence of a Russian project touching the Black Sea, had persuaded Britain to concentrate on the eastern Mcditerranean. When the Russian project fell, the clause concerning the Balkans had been inserted at the last moment as a pledge of the two parties' concern with Romania. Once the declaration had been issued, translating this clause into an effective and specific Turco-British guarantee to Romania became once again the core of the negotiations. ${ }^{113}$

As London saw it, the only juridically foolprof method of ensuring Turkish help for Romania was for Turkey to be a belligerent. Britain therefore looked for a formula which would have placed Turkey at war, even nominally, at the same time that Britain became involved in hostilities as a result of implementing the guarantce. The point, of course, was to obtain passage through the Straits. With this aim in mind London, on June 4, proposed a draft agrrement, by which Turkey was to give Grecce and Romania an undertaking of all aid and assistance tantamount to a promise of belligerence whenever the Western pledges came into operation - in effect, a guarantee. In the British view, a direct Turkish guarantee to Greece involved no further obligation than Turkey had already assumed in the declaration, and the crucial factor in introducing this provision in the draft was to facilitate the introduction of the much more essential similar clause about Romania. ${ }^{114}$

The other portions of the British draft granted the Turkish reservation about a Russian attack on Romania, both because it was a sine qua non of Turkish policy and because Britain's interest in Romania extended to its independence, not its territorial integrity. Turkey's qualms about a possible Italian neutrality, in which case there would presumably be no war in the Meditteranean, were discounted by the British Foreign Office on the grounds that the signature of the Pact of Steel had greatly diminished that possibility. The crucial point was Turkey's unwillingness to assume commitments in the Balkans unless its security was directly threatened and here London produced the counter argument that any attack on Romania presented a real threat to Turkey. Therefore, Halifax concluded that it was best to provide for that threat by joining in the Western guarantee to Romania, thus creating a climate of opinion which would not only stiffen the Romanians' will to resist but also contribute to deter an eventual aggressor. ${ }^{115}$

It was significant that the first question raised by Saraçoğlu on June 4, when handed these British proposals concerned the delay in presenting a

113Ibid., No. 687, Halifax to Knatchbull-Hugeessen (Ankara), 4 June 1939.

114 Ibid.

115 Ibid. 
cmmunication on financial and military questions. ${ }^{116}$ His position was that Turkey had continually emphasised that it expected Britain to make good the anticipated loss of trade with Germany, as well as the deficiencies in armaments resulting from Germany's non-delivery of existing orders. ${ }^{117}$ Turkey's abadonment of neutrality in May had not only cut off German war supplies, but had also enhanced its need for them by greatly increasing the chances of being involved in a war. Britain's temporising in this matter was causing a loss of morale, not only in Turkey but in Greece and Romania as well. ${ }^{118}$ A reply, therefore, would be held up until Britain made some answer on the list of supplies requested by Turkey. 119

Essentially, what the Turks wanted in the economic and financial fields were loans and credits to buy armaments, alternative markets for their staple products and alternative sources of supply in the event of Germany cutting off trade altogether. While the Western powers were quite aware that failure to satisfy these requirements might imperil Turkey's adherence to the containment front, they were also quite determined to make all financial arragements depend on the conclusion of a satisfactory political agreement rather than the other way round, as scemed to be Turkey's intention. London, at the end of June, was prepared to grant Turkey further credits of ten million pounds (in addition to a sixteen million pounds credit arranged in 1938) as well as to offer delivery within twelve months of war materials valued at six million pounds. But there were serious limits, caused by its own armament programme, and the drain on its hard-currency reserves, beyond which Britain could not go. London, for example, reckoned it could supply little more than one-tenth of the requirements estimated by Ankara. An additional sum of five million pounds had been budgeted for credits to Turkey, but was kept as a reserve and not mentioned at this stage. Regarding altemative markets, Britain protested that it could not absorb any more raw products and suggested Turkey to try the Russians. Finally, a cash loan was thought to be out of the question owing to Britain's exchange position; KnatchbullHugessen was instructed to avoid discussing this topic. 120

The Turks estimated their needs much higher. They recalled it had been agreed since the beginning of the negotiations that Turkey's cooperation in the containment front would only be possible with substantial military and financial support. On 14 July, they put forth a comprehensive

116Ibid., No. 709 and fn. 2, Knatchbull-Hugessen (Ankara) to Halifax, 4 June 1939.

117 Ibid., No. 512, Knatchbull-Hugessen (Ankara) to Halifax, 13 May 19389.

118 Ibid., Vol. 6, No.s 82 and 98, Knatchbull-Hugessen (Ankara) to Halifax. 18 and 20 June 1939.

119 Ibid., No. 168, Knatchbull-Hugessen (Ankara) to Halifax, 29 June 1939.

${ }^{120}$ Ibid., No. 169. Halifax to Knatchbull-Hufessen (Ankara), 29 June 1939. 
plan which included thirtyfive million pounds credit for a rearmament programme (including reorganising the Turkish armaments industry and placing orders in the United States, Belgium and Sweden), a bullion loan of fifteen million pounds to support the Turkish currency and a further credit of ten million pounds for urgent armaments purchases, and to free all frozen balances before devaluing the Turkish lira and placing all trade on a compensation basis. Turkey also insisted on meeting the service of the fifteen million pounds with deliveries of tobacco. It urged Britain and France to get together to see how best they could meet these requirements and in what proportion. 121

The French reaction to this last suggestion was that since they had already made a substantial sacrifice with the return of Hatay, they ought to be dispensed from giving Turkey further economic assistance. ${ }^{122}$ The argument was, of course, entirely unconvincing since Hatay was not French territory, and the retum did not involve any financial sacrifice. London's attitude was that the Turks had overestimated their needs, but that they sohuld be met for political reasons. ${ }^{123}$ As it finally turned out, by the time the Turco-AngloFrench treaty was signed on 19 October, Turkey had been granted the larger share of these demands and had also succeeded in reversing the British condition that financial assistance should follow the political agreement.

In the political negotiations, the Western powers were in an equally unenviable bargaining position. They needed Turkey, which they had cast as the linchpin of the containment front in the Balkans, more than Turkey needed them for, in the last analysis, Turkey could always opt for neutrality,

Agreement in principle on the draft treaty was reached on September 1 , and at the same time Turkey obtained from Britain a ten million pounds credit for arms purchases and a three million bullion pounds loan later increased to five million pounds with no interest in the first year. On the political provisions, Britain and France not only gave way on their request for reciprocity but also guaranteed Turkey unilaterally against a European power, understood to be either Bulgaria or Germany. ${ }^{124}$

In the summer months of 1939, Britain and France sought to establish a common front with the Sovict Union, in view of the German threats to world peace. Turkey followed these developments with close concern and

${ }^{121}$ Ibld., No. 320, Knatchbull-Hugessen (Ankara) to Halifax, 14 July 1939.

122Ibid., No. 555, Halifax to Campbell (Paris), 4 August 1939.

123 Ibid., No. 331, Knatchbull-Hugessen (Ankara) to Halifax, 15 July 1939.

124 Ibid., Vol. 7, No. 550, Knatchbull-Hugessen (Ankara) to Halifax, 30 August 1939; Ibid., No.s 661 and 667. Halifax to Knatchbull-Hugessen (Ankara), 1 September 1939. 
attention, interested as it was in the strengthening of the peace front. The conclusion of the Nazi-Soviet pact of 23 August 1939 gave Turkish leaders a severe shock. The Turks, Massigli informed Paris. reacted to it with a 'sentiment near to stupor and lost themselves in conjectures, most often pessimistic, on the motives that had inspired Joseph Stalin's decision'. Their disappointment was keen when they learned that their formidable Soviet neighbour, hitherto friendly and since 1934 openly espousing the status quo and collective security, had joined hands with the Nazi proponents of armed revision. It meant, moreover, that their friendship with Britain and France, instead of being approved, would now be criticised in Moscow. 125

Turkey, however, continued to search for the illusive Sovict connection to parallel its accommodation with Britain and France. Thus on September 25, Saraçoğlu left for Moscow for the purpose of concluding a new agreement with the Soviet Union. Conversations towards such an agreement had been going on for some time between the Soviet ambassador at Ankara and the Turkish government. Turkey desired an agreement that would reaffirm Soviet support of the status quo in the Black Sea region and by the same token confirm Soviet respect of Turkish independence and territorial integrity, which could clear the way for a proposed Turkish allance with Britain and France. Soviet objectives were quite different. Having moved closer to Germany, it now resented the prospect of a Turco-Anglo-French alliance. To keep Turkey away from cooperating with the West was at that time one of the major objectives of German foreign policy. ${ }^{126}$

Germany needed the aid of the Soviet Union, who as a close and powerful neighbour was in a much stronger position to press for a change in Turkish policy. Both to appease Germany and to keep the conflict away from its borders, the Soviet Union desired Turkish neutrality. Thus considering the basic divergence in objectives, it was no wonder that Saraçoğlu's mission to Moscow failed. ${ }^{127}$

The general policy of Turkey was restated succinctly by Hüseyin Cahit Yalçın in Istanbul daily Yeni Sabah of 5 October:

When, as a consequence of the invasion of Czechoslovakia, the German expansionist claims and the destruction of Albania, Turkey was awakened to the danger of an attack on the Balkans, it associated itself with the peace front. It did its best to include its close friend the Soviet Union into this association. While Turkey was converting its

125 D.D.F., Ser. 2, Vol. 18, No. 281, Massigli (Ankara) to Bonnet, 23 August 1939

126 Erkin, Les Relations Turco-Soviétiques, pp. 154-157 and 163-168.

${ }^{127}$ N. Sadak, Turkey Faces the Soviets', Foreign Affairs, April 1949, pp. $452-454$ 
understanding with the democracies into a long-term pact, it kept its friend Russia informed of all the stages of these negotiations. In this matter Turkey received from the Soviet Union nothing but friendly expressions of satisfaction and approval. Turkey considers its relations with its neighbour, the Soviet Union, to be as important as its relations with the democracies. It definitely does not wish to make a choice between its friends in the East and in the West, or to take up a position hostile to either. Consequently it is impossible that the basis of our alliance with the Western democracies should give offence to Russia, or that we should abandon the basis of that alliance. In the event of war for any reason between the Western democracies and the Soviet Union, Turkey can do its Eastern and Western friends no better service than by maintaining a sinceree neutrality.

By that time Turco-Anglo-French discussions for a definitive alliance were far advanced and most of the major points of the agreement setuled. In order to reconcile its Western friendship with Soviet objections, Turkey was willing to formulate its proposed alliance with Britain and France in such a way that it would explicitly exclude any common anti-Soviet action. this concession was made with the approval of the British and the French, who fully understood Turkey's difficult position. On October 19, two days after Saraçoğlu's return to Ankara, the Turco-Anglo-French treaty was signed. Protocol No. 2 absolved Turkcy from any action calculated to bring it into conflict with the Soviet Union. Otherwise, Turkey and the two Western powers mutually undertook to lend one another all assistance in their power, whether a war arising out of the Anglo-French guarantees to Grecce and Romania or a European act of aggression against Turkey.

A special secret agreement stipulated a credit to Turkey of twenty-five million pounds for the purchase of war materials; the immediate delivery of orders already placed against this credit; the creation of a commission to decide what further materials Turkey necded to resist aggression; a loan of fifteen million pounds in gold, interest and capital repayable in Turkish Liras which, however, had to be used to purchase Turkish commodities. Article 6 of the special secret agrecement laid down that Turkey was not obliged to fulfil the obligations of the political treaty until after it had received delivery on all the outstanding war materials on order as well as the new orders to be decided by the commission and the gold loan. The tripartite treaty also included a wide-ranging military convention covering a number of hypotheses to be discussed, problems of troop transport and allied based on Turrkish territory including the Sea of Marmara but not, owing to the Russian clause, the Black Sea. Lastly to prove that the Russian clause would not be used as an excuse for Turkey's withdrawal if the Soviet Union intervened in a conflict 
already under way, the Turks inserted a provision forbidding a separate peace or armistice. ${ }^{128}$

The signature of the tripartite treaty was unquestionably a great diplomatic success for Britain and France. Alhough structured on the basis of the Turco-British declaration, this treaty went even further by reinforcing some of its clauses and including a clear-cut definition of the conditions under which the obligations for mutual aid should come into force. The British policy of guarantees in respect of Turkey was at long last embodicd in a formal treaty and Britain had succeeded in drawing Turkey within the orbit of the Allies. Turco-Biritish friendship of the nineteenth century was one thing; it sprang largely from apprehension of the designs of Tsarist Russia. TurcoBritish friendship of October 1939 was a different thing. No longer was it a question of bolstering up the 'sick man of Europe', but of sharing ideals and resolves with a virile nation, conscious of its strength and determined to fulfil the role which geographical considerations alone had decreed to them. On the part of Turkey, the tripartite alliance represented two things. First, it was the final harvest of a Turkish policy of realignment followed since 1935. to which Britain was brought to accede only by the political dangers of 1939. Ankara was on the closest terms with London, if only because Turkey and Britain had, in essence, the same ideals for peace, and manifestly common interests. Secondly, it represented the turning point of Turkey to the West and, thus, was of considerable importance in relation to Turkish policy after 1945 .

There can in history be few more vivid examples of the turning of enemies into friends than that provided by Turkey and Britain. During the Great War, the Ottoman Empire and the British Empire were at grips in a life-and-death struggle. The bitterness of that strife survived the armistice, and for the Turkish nationalist sentiment arising on the ruins of the Ottoman Empire, the British officially had no sympathy. The Treaty of Lausanne succeeded the Treaty of Sèvres; and still the Turks felt that Britain was their chief enemy. As Turkey grew more confident in its own strength, it also grew less suspicious of British motives towards it. It was notably after the emergence of the Italian menace in the eastern Mediterranean in the mid1930s that an atmosphere was created in which both the Turkish and British governments could work for a ncw understanding. The difficulties had been considerable, but goodwill on either side had surmounted them, and the Treaty of Mutual Assistance that came up was a vindication of the vision and patience of both Ankara and London.

${ }^{128}$ The text of the treaty is in League of Nations Treaty Serles, Vol. CC, pp. 167-175; the secret protocols are outlined in Massigli, L a Turquie devant la Guerre, 292-295. 